\title{
Synthesis and Evaluation of Biological Activities of Bis(spiropyrazolone)cyclopropanes: A Potential Application against Leishmaniasis
}

\author{
Olalla Barreiro-Costa ${ }^{1, \dagger}$, Gabriela Morales-Noboa ${ }^{2,+}$, Patricio Rojas-Silva ${ }^{1}$, Eliana Lara-Barba ${ }^{2} \mathbb{D}$, \\ Javier Santamaría-Aguirre ${ }^{2}{ }^{(D}$, Natalia Bailón-Moscoso ${ }^{3}\left(\mathbb{D}\right.$, Juan Carlos Romero-Benavides ${ }^{4}{ }^{\oplus}$, Ana Herrera ${ }^{3}$,
} Cristina Cueva ${ }^{3}$, Lenin Ron-Garrido ${ }^{2}$, Ana Poveda ${ }^{2, *} *$ and Jorge Heredia-Moya ${ }^{1, * \mathbb{C}}$

1 Centro de Investigación Biomédica (CENBIO), Facultad de Ciencias de la Salud Eugenio Espejo, Universidad UTE, Quito 170527, Ecuador; olallabarreirocosta@gmail.com (O.B.-C.); projas1@usfq.edu.ec (P.R.-S.)

2 DNA Replication and Genome Instability Unit, Grupo de Investigación en Biodiversidad, Zoonosis y Salud Pública (GIBCIZ), Instituto de Investigación en Zoonosis-CIZ, Facultad de Ciencias Químicas, Facultad de Ciencias Agrícolas, Universidad Central del Ecuador, Quito 170521, Ecuador; gemoralesnoboa@hotmail.com (G.M.-N.); eliluci1@hotmail.com (E.L.-B.); jrsantamaria@uce.edu.ec (J.S.-A.); ljron@uce.edu.ec (L.R.-G.)

check for

updates

Citation: Barreiro-Costa, O.;

Morales-Noboa, G.; Rojas-Silva, P.;

Lara-Barba, E.; Santamaría-Aguirre, J.;

Bailón-Moscoso, N.;

Romero-Benavides, J.C.; Herrera, A.; Cueva, C.; Ron-Garrido, L.; et al.

Synthesis and Evaluation of

Biological Activities of

Bis(spiropyrazolone)cyclopropanes:

A Potential Application against Leishmaniasis. Molecules 2021, 26 4960. https://doi.org/10.3390/ molecules26164960

Academic Editors: Andrew Tsotinis and Ioannis Papanastasiou

Received: 1 July 2021

Accepted: 2 August 2021

Published: 17 August 2021

Publisher's Note: MDPI stays neutral with regard to jurisdictional claims in published maps and institutional affiliations.

Copyright: (c) 2021 by the authors. Licensee MDPI, Basel, Switzerland. This article is an open access article distributed under the terms and conditions of the Creative Commons Attribution (CC BY) license (https:/ / creativecommons.org/licenses/by/ $4.0 /)$.
3 Departamento de Ciencias de la Salud, Universidad Técnica Particular de Loja, Loja 1101608, Ecuador; ncbailon@utpl.edu.ec (N.B.-M.); agherrera5@utpl.edu.ec (A.H.); mccueva5@utpl.edu.ec (C.C.)

4 Departamento de Química, Universidad Técnica Particular de Loja, Loja 1101608, Ecuador; jcromerob@utpl.edu.ec

* Correspondence: apoveda@uce.edu.ec (A.P.); jorgeh.heredia@ute.edu.ec (J.H.-M.)

$\dagger$ These authors contributed equally to this work.

Abstract: This work focuses on the search and development of drugs that may become new alternatives to the commercial drugs currently available for treatment of leishmaniasis. We have designed and synthesized 12 derivatives of bis(spiropyrazolone)cyclopropanes. We then characterized their potential application in therapeutic use. For this, the in vitro biological activities against three eukaryotic models-S. cerevisiae, five cancer cell lines, and the parasite L. mexicana-were evaluated. In addition, cytotoxicity against non-cancerous mammalian cells has been evaluated and other properties of interest have been characterized, such as genotoxicity, antioxidant properties and, in silico predictive adsorption, distribution, metabolism, and excretion (ADME). The results that we present here represent a first screening, indicating two derivatives of bis(spiropyrazolone)cyclopropanes as good candidates for the treatment of leishmaniasis. They have good specificity against parasites with respect to mammalian cells.

Keywords: bis(spiropyrazolone)cyclopropanes; drugs; leishmaniasis cytotoxicity; ADME

\section{Introduction}

Heterocycles are common structural motifs in marketed drugs. Many have at least one heterocycle in their structure and are the target of medicinal chemistry in the drug discovery process [1]. Nitrogen-containing rings in particular play an important role in drug development due to their wide variety of therapeutic and pharmacological properties. Pyrazoles and their derivatives can be analgesic, anti-inflammatory, antipyretic, antioxidant, anticonvulsant, antidepressant, antihyperglycemic, antimicrobial, antiviral, antitumor, hepatoprotective, and spasmolytic [2-4]; several drugs currently on the market have a pyrazole ring as the key structural motif [5].

Derivatives of 2,4-dihydro-3H-pyrazol-3-one include edaravone (1), a powerful antioxidant [6], and 4,4'-(arylmethylene)bis(1-phenyl-3-methyl-1H-pyrazol-5-ol) (2). These have a wide spectrum of reported biological activities and have been used as anti-inflammatory, antipyretic agents, stimulants of gastric secretions, antidepressants, antibacterial agents 
and filaricides. These pyrazole-5-ols have been used as fungicides, pesticides, insecticides, and dyes [7]. However, despite the great variety of reported activities of these heterocycles, there are virtually no studies on leishmanicidal [8] or cytotoxic activity against tumor cells. Of the few similar compounds studied, the derivatives of phenyl pyrazolones are interesting despite not showing good leishmanicidal activity because they are intermediates in the synthesis of 4,4'-(arylmethylene)bis(1-phenyl-3-methyl-1H-pyrazol-5-ols) [9]. An analysis of these compounds shows that their structure is similar to $3,3^{\prime}$-(arylmethylene)bis(2hydroxynaphthalen-1,4-diones) [10] and 3,3'-diindolylmethanes [11], which possess potent leishmanicidal activity. Thus, the study of $1 \mathrm{H}$-pyrazole-5-ol and similar compounds against these parasites is of interest.

Thus, our laboratory has worked on the synthesis of 4,4'-(arylmethylene)bis(1-phenyl3-methyl- $1 \mathrm{H}$-pyrazole-5-ols) and assayed them against in vitro models previously implemented in our laboratory. We found that these compounds have good antioxidant activity in vitro, as well as cytotoxicity against the RKO cell line [12]. We found good leishmanicidal activity against promastigotes of Leishmania mexicana and the evaluation of the anti-trypanosomatid activity of these compounds is in progress and will be reported elsewhere.

A structural analysis of the active principles of medicinal agents that are currently on the market shows that several of them incorporate cyclopropane. Some of these drugs have a high market demand including montelukast and ciprofloxacin. Molecules that incorporate this ring in their structure have received considerable attention because they exhibit a wide range of biological activities, including enzymatic inhibition, insecticide, analgesic, antifungal, phytotoxic, antibiotic, antifungal, antiviral, antitumor and hormonal activities [13-18].

A diverse range of biological activities have also been reported for spirocyclopropanes, such as anti-inflammatory, analgesic, anticancer, and cytotoxic activity [19-22]. The attention from compounds that incorporate this structure has not been limited to molecules of synthetic origin, but rather have focused on natural products because this functionality has been reported in several naturally occurring compounds [23-26]. In the case of spirocyclopropanes bound to heterocycles there are few reports of biological activity. Those that can be found are limited to documenting the antiviral activity [27,28], and their activity as inhibitors of spliceosome [29], alpha-L-fucosidase [30], $\beta$-lactamase [31] and non-nucleoside inhibitors of HIV-1 reverse transcriptase [32]. Of note, ledipasvir is used to treat hepatitis $C$ and has this structural element [33].

Spirocyclopropanes can be easily synthesized from 4,4'-(arylmethylene)bis(1-phenyl3-methyl-1H-pyrazol-5-ol) [34] or directly from 3-methyl-1-phenyl-2-pyrazolin-5-one and benzaldehydes 3 in one step [35]. However, their bioactivity is largely uncharacterized, and the only report found is focused in the inhibitory activity of advanced glycation products (PGA) for the treatment of schizophrenia [36].

Therefore, continuing with our study on the bioactivity of heterocyclic compounds $[37,38]$ and in view of the great structural similarity that spirocyclopropanes present versus the previously studied bispyrazole-5-ol and the antecedents discussed, we report here the synthesis of a series of bis(spiro-2,4-dihydro-3H-pyrazol-3-one) cyclopropanes 4 , starting from 4,4'-(arylmethylene)bis(1-phenyl-3-methyl-1H-pyrazol-5-ol) 2. Their biological activities were evaluated in three models: yeast Saccharomyces cerevisiae, promastigotes of Leishmania mexicana, five human tumor cell lines, and one normal cell line. Additional tests were performed to decipher its mechanism of action (antioxidant and genotoxicity).

\section{Results}

\subsection{Synthesis}

The synthesis of a small library of 4,4'-(arylmethylene)bis( $1 H$-pyrazol-5-ols) $2 \mathbf{a}-\mathbf{u}$ was performed through an efficient synthetic approach using $\mathrm{NaOAc}$ as catalyst as previously reported (Scheme 1) [12]. The optimal conditions consist of the reaction of the pseudo-threecomponent substituted benzaldehyde 3a-u with two equivalents of 3-methyl-1-phenyl2-pyrazolin-5-one (1) at room temperature using $70 \% \mathrm{EtOH}$ as solvent. This leads to 
the corresponding 4,4'-(arylmethylene)bis(1-phenyl-3-methyl-1H-pyrazol-5-ol) derivatives 2a-u in good to excellent yield (Table 1).

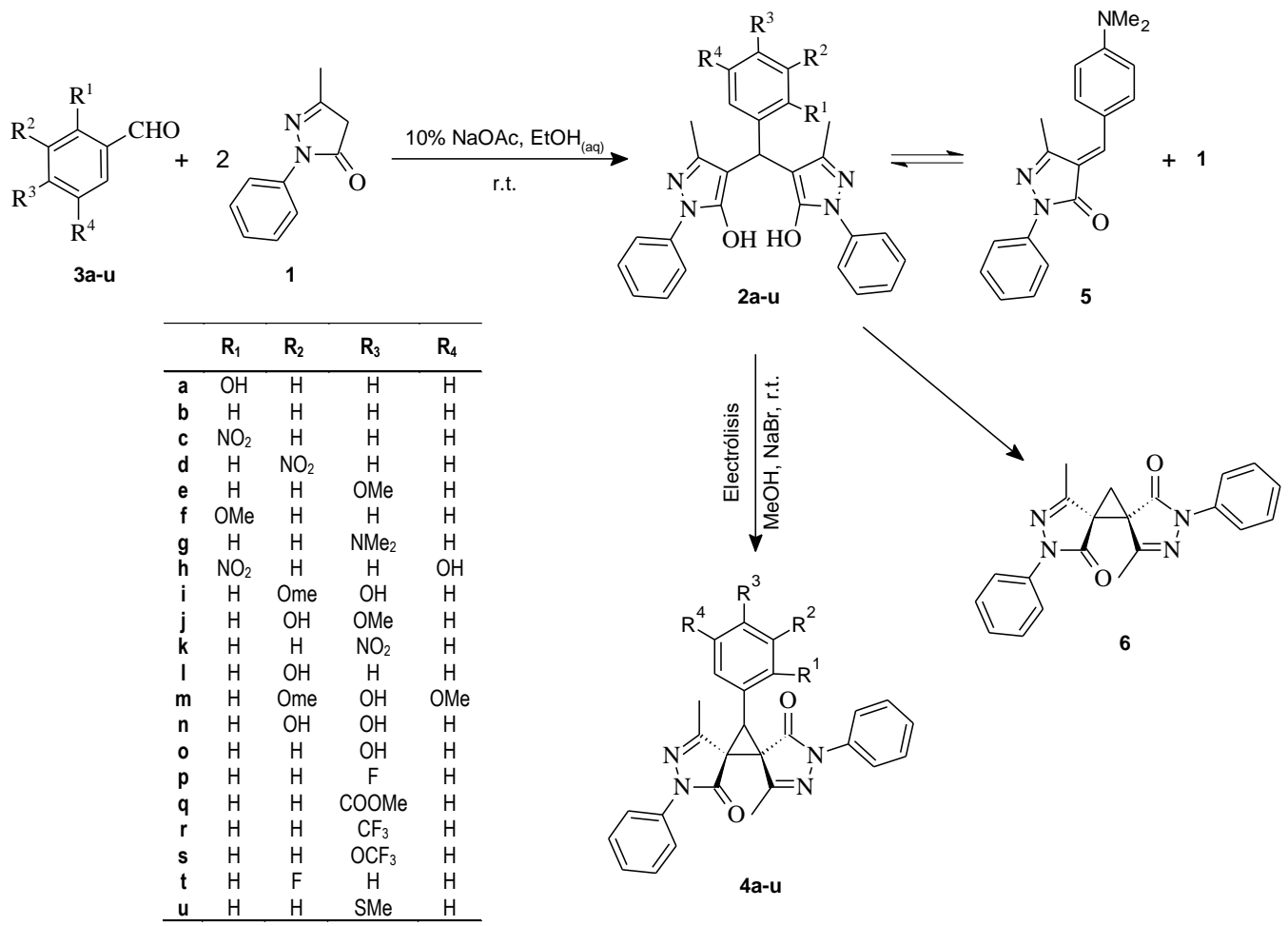

Scheme 1. Synthesis of bis(pyrazol-5-oles) 2 and bis(spiropyrazolone)cyclopropanes 4.

Table 1. Synthesis of bis(pyrazol-5-oles) 2 and bis(spiropyrazolone)cyclopropanes 4.

\begin{tabular}{|c|c|c|c|}
\hline Entry & Aldehyde & $\begin{array}{c}\text { Yield } 2 \\
(\%)\end{array}$ & $\begin{array}{c}\text { Yield } 4 \\
(\%)\end{array}$ \\
\hline 1 & $3 a$ & 98 & - $^{\mathrm{a}}$ \\
\hline 2 & $3 b$ & 97 & 81 \\
\hline 3 & $3 c$ & 95 & 70 \\
\hline 4 & $3 d$ & $95^{b}$ & 91 \\
\hline 5 & $3 e$ & 92 & 87 \\
\hline 6 & $3 f$ & 95 & 77 \\
\hline 7 & $3 g$ & $84^{\mathrm{d}}$ & $60^{c}$ \\
\hline 8 & $3 \mathrm{~h}$ & 93 & $\ldots$ a \\
\hline 9 & $3 \mathbf{i}$ & $94^{\mathrm{e}}$ & - $^{\mathrm{a}}$ \\
\hline 10 & $3 \mathbf{j}$ & $91^{\mathrm{d}}$ & $-^{a}$ \\
\hline 11 & $3 k$ & 97 & 54 \\
\hline 12 & 31 & $98^{\mathrm{d}}$ & - $^{\mathrm{a}}$ \\
\hline 13 & $3 m$ & $97^{\mathrm{e}}$ & $-^{a}$ \\
\hline 14 & $3 n$ & $93^{\mathrm{e}}$ & - $^{\mathrm{a}}$ \\
\hline 15 & 30 & $97^{\mathrm{d}}$ & - $^{\mathrm{a}}$ \\
\hline 16 & $3 p$ & 87 & 47 \\
\hline 17 & $3 q$ & Quant. & 85 \\
\hline 18 & $3 r$ & 96 & 87 \\
\hline 19 & $3 s$ & Quant. & 70 \\
\hline 20 & $3 t$ & Quant. & 84 \\
\hline 21 & $3 u$ & 60 & 64 \\
\hline
\end{tabular}

a Complex mixture; ${ }^{\mathrm{b}}$ Using $100 \%$ EtOH; ${ }^{\mathrm{c}}$ Product $5 ;{ }^{\mathrm{d}}$ Using 60\% EtOH; ${ }^{\mathrm{e}}$ Using 50\% EtOH.

The spectroscopic data and melting points of compounds previously reported agreed with literature values. As expected, the reaction time showed the same substituent effect as previously observed [12], except for $\mathbf{2 g}$. These had strong electron-donating dimethylamino 
group in $\mathbf{3 g}$, and the possibility of the formation of a tautomeric quinoid structure $[39,40]$ could explain the reduction of the activity of this benzaldehyde (entry 8).

The synthesis of 4 was performed using the electrocatalytic cyclization of $\mathbf{2}$ as previously reported (Scheme 1) [34]. The reaction was made using a 6 V, $800 \mathrm{~mA} \mathrm{D.C.} \mathrm{power}$ supply, and pure product was obtained after filtration in good to moderate yields (Table 1). However, no product was obtained when the starting bispyrazole has hydroxyl groups in its structure. A complex mixture was observed in these cases.

The presence of many products in these mixtures suggests the possibility of other reactions that compete with the desired one. Spirocyclopropanes 4 are known to isomerize to 4-[(pyrazol-4-yl)-methylene]pyrazolones when in solution, especially in DMSO and high temperature [41]. In our experience, however, this isomerization is observed even at low temperature. Structure 2 is reported to be thermo labile and suffer a retro-Michael reaction when in solid state or in solution; this stability is influenced by the presence of the different substituents in the aromatic ring [42]. Electron-acceptor groups increase the stability of 2, while electron-donor groups reduce their stability. Thus, a more complex mixture is expected. In the case of $\mathbf{2 g}$, the main product of the reaction is the $1 \mathrm{H}$-pyrazol$5(4 H)$-one 5 with a yield of $60 \%$ (Entry 7 ). For 21, it was possible to isolate a small amount of bis(spiropyrazolone)cyclopropane 6, which was characterized by 2D-NMR. This also suggests that, in addition to the retro-Michael reaction, there would also be decomposition reactions of the bis(spiropyrazolone)cyclopropanes formed.

\subsection{Biological Activity of Bis(spiro pyrazolone)cyclopropanes against Yeast S. cerevisiae, and Human Cancer Cell Lines}

The sensitivity to all synthesized bis(spiropyrazolone)cyclopropanes 4 was evaluated against five human cancer cell lines (RKO, A-549, MCF-7, PC-3 and HeLa) and budding yeast $S$. cerevisiae (W303 strain). First, the effect on viability of human cancer cell lines was assessed using the MTS assay. Cells were treated with $100 \mu \mathrm{M}$ of each derivative for $48 \mathrm{~h}$ and doxycycline was used as control. The strongest effect was obtained with the derivative $4 \mathbf{s}$, with $70.23 \%$ of cellular inhibition in the RKO cell line (Table S1).

Next, we determine the inhibitory concentration fifty $\%, \mathrm{IC}_{50}$ (Table 2). The lines most sensitive to the compounds (RKO, PC-3 and Hela) were selected. The $\mathrm{IC}_{50}$ was established in those that inhibited more than $50 \%$ of cell growth in any of these three cell lines (Table S1). Here, cells were exposed to each compound in concentrations ranging between 15 and $150 \mu \mathrm{M}$. The $\mathrm{IC}_{50}$ calculated for the derivatives shows values from $49.79 \mu \mathrm{M}$ to $113.70 \mu \mathrm{M}$. Derivative $4 \mathbf{r}$ was the most potent in RKO, PC-3 and HeLa cell lines with $\mathrm{IC}_{50}$ values of $60.70 \mu \mathrm{M}, 49.79 \mu \mathrm{M}$, and $78.72 \mu \mathrm{M}$, respectively. The less potent derivatives were $4 \mathrm{~d}$ and 4q. Finally, the cell morphology of RKO, PC-3 and HeLa cell lines exposed to the $\mathrm{IC}_{50}$ of the most active bis(spiro-2,4-dihydro-3H-pyrazol-3-one) cyclopropanes for $48 \mathrm{~h}$ was checked microscopically to confirm the effect of the compounds (Figure S1). Overall, our results show that derivatives $\mathbf{4 d}, \mathbf{4 k}$, and $\mathbf{4 q}$-s exert a reliable inhibitory activity on human cancer cell lines RKO, PC-3 and HeLa, but not on A-549 nor MCF-7. However, the $\mathrm{IC}_{50}$ values are relatively high for potential anticancer drugs.

Next, we determined the $\mathrm{IC}_{50}$ of bis(spiropyrazolone)cyclopropanes on a different eukaryotic model: the classical budding yeast $S$. cerevisiae. Cells were exposed to the compounds at concentrations ranging from 2.6 to $3000 \mu \mathrm{M}$ for $24 \mathrm{~h}$. The OD600 was measured to assess cell growth. No compound showed significant bioactivity; $\mathbf{4 q}$ and 4s were the only ones showing a slight measurable effect (Table S2). These resistances could be explained by the presence of the fungal cell wall, which could limit the entry of bis(spiropyrazolone)cyclopropanes 4 into the cell. Other mechanisms cannot be ruled out, such as structural differences in molecular targets. 
Table 2. Inhibitory activity of bis(spiropyrazolone)cyclopropanes 4 against human cancer cell lines, reported as $\mathrm{IC}_{50}(\mu \mathrm{M})$.

\begin{tabular}{cccc}
\hline & \multicolumn{3}{c}{ Human Cancer Cell Lines } \\
\hline $\mathbf{4 b}$ & RKO & PC-3 & HeLa \\
$\mathbf{4} \mathbf{c}$ & $\mathrm{NE}$ & $\mathrm{NE}$ & $\mathrm{NE}$ \\
$\mathbf{4} \mathbf{d}$ & $\mathrm{NE}$ & $\mathrm{NE}$ & $\mathrm{NE}$ \\
$\mathbf{4} \mathbf{e}$ & $93.97 \pm 4.09$ & $90.87 \pm 2.56$ & $94.79 \pm 4.54$ \\
$\mathbf{4} \mathbf{N}$ & $\mathrm{NE}$ & $\mathrm{NE}$ & $\mathrm{NE}$ \\
$\mathbf{4 k}$ & $\mathrm{NE}$ & $\mathrm{NE}$ & $\mathrm{NE}$ \\
$\mathbf{4} \mathbf{p}$ & $84.00 \pm 9.46$ & $83.18 \pm 0.45$ & $113.70 \pm 6.37$ \\
$\mathbf{4 q}$ & $\mathrm{NE}$ & $\mathrm{NE}$ & $\mathrm{NE}$ \\
$\mathbf{4 r}$ & $102.20 \pm 7.80$ & $108.80 \pm 2.77$ & $85.07 \pm 10.52$ \\
$\mathbf{4} \mathbf{s}$ & $60.70 \pm 9.95$ & $49.79 \pm 5.51$ & $78.72 \pm 7.90$ \\
$\mathbf{4 t}$ & $63.80 \pm 6.48$ & $70.27 \pm 1.90$ & $78.45 \pm 7.08$ \\
$\mathbf{4 u}$ & $\mathrm{NE}$ & $\mathrm{NE}$ & $\mathrm{NE}$ \\
$\mathbf{D o x}$ & $\mathrm{NE}$ & $\mathrm{NE}$ & $\mathrm{NE}$ \\
\hline & $0.51 \pm 0.01$ & $0.65 \pm 0.08$ & $1.23 \pm 0.10$ \\
\hline
\end{tabular}

Finally, a drop test assay was performed in different yeast strains (Figure S2). The sensitivity was determined in wild type yeast strain (W303 genetic background) as well as in strains harboring mutations in checkpoint pathways genes as well as those involved in signaling DNA damage lesions and/or DNA replication blocking situations. Frequently mutating strains are more sensitive to drug exposure than the wild type. This strategy hints of the mechanism of action of the analyzed drugs. The stock solutions were prepared in DMSO due to the low solubility of the compounds in ethanol. However, fresh solutions were prepared for each experiment and used immediately to avoid decomposition problems. Serial dilutions of yeast cells suspensions were spotted onto plates with compounds $4 \mathbf{a}-\mathbf{u}$ to $0.2 \mathrm{mg} / \mathrm{mL}$ (from a fresh stock in DMSO at $4 \mathrm{mg} / \mathrm{mL}$ ) and incubated at $28^{\circ} \mathrm{C}$ for $72 \mathrm{~h}$. As a plate without drug, a plate with DMSO and a plate with genotoxic MMS $0.033 \%$ were included as controls. Control without drugs and with DMSO did not show any difference in growth indicating that DMSO is not toxic at these concentrations. However, some strains are clearly unable to grow in the presence of MMS. Our results show that neither the wild type nor the mutant strains are sensitive to any of the bis(spiropyrazolone)cyclopropanes 4 and could grow without major problems.

These observations suggest that bis(spiropyrazolone)cyclopropanes 4 do not generate DNA damage or checkpoint activation in budding yeast. It is plausible that the entry of the compounds is limited by the fungal cell wall in agreement with the high resistance observed for wild type and for mutants (Table S2, Figure S2, see Section 3).

\subsection{Evaluation of Cytotoxic and Leishmanicidal Activity}

We next evaluated the leishmanicidal activity of the bis(spiropyrazolone)cyclopropane 4. The activity was evaluated in vitro against promastigotes of Leishmania mexicana and cytotoxicity against RAW 264.7 macrophages. Serial dilutions were immediately made in the culture medium from a fresh stock in DMSO prepared immediately before use to prevent degradation. A range of solutions from 100 to $0.001 \mu \mathrm{M}$ were prepared for the assay. All compounds showed very good anti-leishmanicidal activity with $\mathrm{IC}_{50}$ values below $1 \mu \mathrm{M}$, except $4 \mathbf{e}$ and $4 \mathbf{f}$, that have an $\mathrm{IC}_{50}$ value of $1.48 \mu \mathrm{M}$ and $2.23 \mu \mathrm{M}$, respectively. Compounds $4 \mathbf{b}$-d and $4 \mathbf{r}-\mathbf{s}$ are the most active against leishmania with an $\mathrm{IC}_{50}$ ranging from $0.15 \mu \mathrm{M}$ to $0.19 \mu \mathrm{M}$. These are statistically comparable to values observed for amphotericin B $(0.17 \mu \mathrm{M})$ (see Statistical Analyses S1).

No evidence of degradation of the compounds was observed in the solutions used for treatments. The stability of $100 \mu \mathrm{M}$ solutions of $4 \mathbf{b}$ in DMSO and PBS 1X pH 7.4 was evaluated using spectroscopic measurements (Figure S3), obtaining an approximate halflife for the solution of $4 \mathrm{~b}$ in DMSO at room temperature for $7.85 \mathrm{~h}$ ( $471 \mathrm{~min})$. On the other 
hand, the solution of 4 in PBS at the same conditions showed no evidence of degradation. Next, stock solutions underwent in situ isomerization to confirm that the activity is due to spyrocyclopropanes 4 and not due to their products of thermal degradation. Here, each stock solution of 4 in DMSO was heated to $100^{\circ} \mathrm{C}$ for $5 \mathrm{~min}$ prior to the biological evaluation [41]. No effect was observed with any compounds after treating the parasite with $10 \mu \mathrm{M}$ concentration solutions (Figure S3).

Next, we calculated the selectivity index (SI) (Table 3), and ranges from 4.9 to 45.3; $4 \mathbf{s}$ has the highest SI. In the case of $\mathbf{4 b}, \mathbf{4} \mathbf{c}$ and $4 \mathbf{d}$, there is an SI of 21.3, 15.3 and 26.0, respectively. Compounds will be more effective and stable during treatment with a higher selectivity index.

Table 3. Inhibitory activity of bis(spiropyrazolone)cyclopropanes 4 against promastigotes of L. mexicana and cytotoxicity in RAW cells and selective indexes.

\begin{tabular}{cccc}
\hline & $\begin{array}{c}\text { Leishmanicidal Activity } \\
\mathbf{I C}_{\mathbf{5 0}} \boldsymbol{\mu M}^{\mathbf{a}}\end{array}$ & $\begin{array}{c}\text { Cytotoxicity } \\
\mathbf{C C}_{\mathbf{5 0}} \boldsymbol{\mu} \mathbf{M}\end{array}$ & $\mathbf{S I}^{\mathbf{b}}$ \\
\hline $\mathbf{4 b}$ & $0.16 \pm 0.00(\mathrm{~d})$ & $3.4 \pm 1.5(\mathrm{~cd})$ & 21.3 \\
$\mathbf{4} \mathbf{c}$ & $0.15 \pm 0.04(\mathrm{~d})$ & $2.3 \pm 0.2(\mathrm{~d})$ & 15.3 \\
$\mathbf{4 d}$ & $0.15 \pm 0.02(\mathrm{~d})$ & $3.9 \pm 1.1(\mathrm{bcd})$ & 26.0 \\
$\mathbf{4} \mathbf{e}$ & $1.48 \pm 0.25(\mathrm{~b})$ & $7.3 \pm 2.0(\mathrm{abd})$ & 4.9 \\
$\mathbf{4} \mathbf{f}$ & $2.23 \pm 0.07(\mathrm{a})$ & $12.8 \pm 1.2(\mathrm{a})$ & 5.7 \\
$\mathbf{4} \mathbf{k}$ & $0.30 \pm 0.09(\mathrm{~cd})$ & $3.3 \pm 1.0(\mathrm{~cd})$ & 11.0 \\
$\mathbf{4} \mathbf{p}$ & $0.57 \pm 0.23(\mathrm{c})$ & $3.5 \pm 0.9(\mathrm{~cd})$ & 14.3 \\
$\mathbf{4 q}$ & $0.28 \pm 0.04(\mathrm{~cd})$ & $4.0 \pm 0.8(\mathrm{bcd})$ & 34.2 \\
$\mathbf{4 r}$ & $0.19 \pm 0.06(\mathrm{~d})$ & $6.5 \pm 0.9(\mathrm{abc})$ & 45.3 \\
$\mathbf{4 s}$ & $0.19 \pm 0.07(\mathrm{~d})$ & $8.6 \pm 3.2(\mathrm{ab})$ & 12.3 \\
$\mathbf{4 t}$ & $0.22 \pm 0.05(\mathrm{~cd})$ & $2.7 \pm 0.7(\mathrm{~d})$ & 22.1 \\
$\mathbf{4} \mathbf{u}$ & $0.42 \pm 0.25(\mathrm{~cd})$ & $9.3 \pm 3.4(\mathrm{a})$ & $>31.8$ \\
$\mathbf{A m p h o ~}$ & $0.17 \pm 0.07(\mathrm{~d})$ & $>5.4$ & \\
\hline
\end{tabular}

a The test for statistical significance was based on one-way ANOVA test. For this, the level of activity was $\log$-transformed $(\log (x+1))$ to reach homoscedasticity criterium, and Tukey test was applied for the post-hoc comparison. The level of significance was set at $5 \%$. Treatments with the same letter are not significantly different.;

b SI (Selectivity Index) = Citotoxic activity/Leishmanicidal activity.

Analysis of the substituents shows that compounds bearing electron-withdrawing groups are more active than compounds with electron-donating ones independent of their location on the ring. In compounds $\mathbf{4 c}, \mathbf{4 d}$ and $\mathbf{4 k}$, all bearing a nitro group, the activity decreases in the order para $>$ ortho $=$ meta, but there is not enough information to make a generalization regarding the location of the substituent and its effect on the leishmanicidal activity. Regarding cytotoxicity, a pattern similar to that found in leishmanicidal activity is observed.

The results shown here indicate that bis(spiropyrazolone)cyclopropanes 4 evaluated here is potentially useful against $L$. mexicana. Compounds $4 \mathbf{r}-\mathbf{s}$ exhibit in vitro activity and a selectivity index comparable to Amphotericin B. Compounds bearing electron-withdrawing groups are more active than compounds with electron-donating ones.

\subsection{Evaluation of Other Activities: Antioxidant and Genotoxicity}

The antioxidant activity of all synthesized bis(spiropyrazolone)cyclopropanes 4 was evaluated by the $N, N$-diphenyl- $N$ '-picrylhydrazyl (DPPH) assay (Table S1). The radical scavenging activity of all compounds was compared with ascorbic acid used as standard. The results show that no radical scavenging activity of any of the compounds evaluated was observed, only $4 \mathbf{k}$ showed activity below $300 \mu \mathrm{M}$.

We quantified DNA breaks by a comet assay to determine if these compounds are genotoxic. Here, L. mexicana cells were exposed for $24 \mathrm{~h}$ to MIC concentrations previously determined (see Materials and Methods Section) for each compound. Figure 1 represents the measurements obtained for tail length. All compounds generated DNA breaks expect 4s. Compounds $\mathbf{4} \mathbf{u}$ and $\mathbf{4 q}$ had the highest genotoxic activity followed by $\mathbf{4 k}$ and $\mathbf{4 t}$. 
Samples with DMSO and MMS (0.011\%) were included as controls. Some representative pictures are shown at Figure S4. The effect of $4 \mathbf{p}$ could not be determined because the cells appear to be very damaged. The data was subjected via a Kruskal-Wallis one-way ANOVA (Statistical Analyses S2). Comet assay results are consistent with leishmanicidal activities showing the biggest genotoxic effects after exposure to $\mathbf{4 k}, \mathbf{4 q}, \mathbf{4 t}$ and $\mathbf{4 u}$ compounds. These observations support a mechanism of action through the generation of DNA damage.

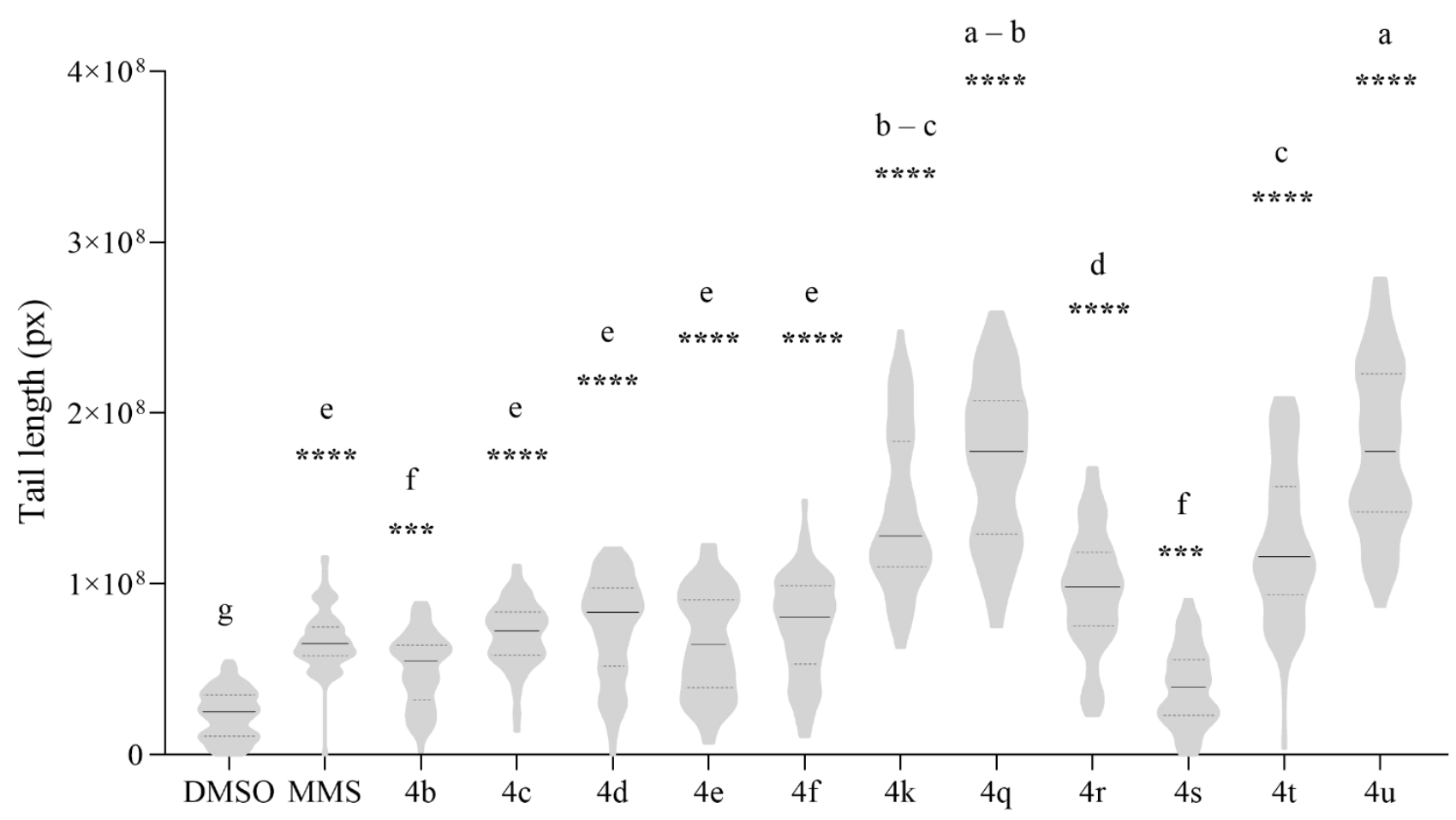

Figure 1. Comet assay of Leishmania mexicana cells exposed to bis(spiropyrazolone)cyclopropanes 4 including Violin plots of tail length measurements from a comet population. Black traits indicate the median and dashed traits including highest and lowest quartiles of each population. DMSO: dimethylsulfoxide; Dox: doxorubicin. The tests for significance were limited to the Kruskal-Wallis one-way ANOVA. Post hoc tests were done via Fisher's least significant difference. Treatments with the same letter are not significantly different. Significance codes: ${ }^{* * * *} p$-value $<0.0001{ }^{* * *} p$-value $<0.001$.

Important limitations to the actual effectiveness of any compound as a therapeutic agent are the safety of a compound in terms of cytotoxicity and genotoxicity towards mammal cells. To address genotoxicity we calculated in silico the theoretical prediction of ADME (adsorption, distribution, metabolism and excretion) properties of compounds $4 \mathbf{b}-\mathbf{u}$ (Table 4).

To evaluate the drug-likeness of a compound, Lipiniski's rule of five (ROF) is usually used, as we did previously [38]. ROF states that good absorption or permeation is more likely when: (a) there are no more than five hydrogen bond donors (HBD); (b) no more than 10 hydrogen bond acceptors (HBA); (c) formula weight less than 500; and (d) noctanol/water partition coefficient $(\log \mathrm{P})$ less than 5 . Two or more violations of ROF suggest the probability of problems in bioavailability [43]. One of the big problems with the development of new drugs is that they usually fail before reaching clinics due to poor pharmacokinetics, and these physicochemical drug descriptors provide a useful tool for evaluating drug activity. We calculated these descriptors for the compounds $4 \mathbf{b}-\mathbf{u}$ using the Osiris DataWarrior software (Table 4) [44]. ADME predictions suggest good bioavailability of compounds $4 \mathbf{b}-\mathbf{k}$, with small limitations of $4 \mathbf{p}-\mathbf{u}$. The compounds $4 \mathbf{r}$ and $4 \mathrm{~s}$ have the worst predictions, with two violations of ROF. In addition, no compound shows a predicted behavior of mutagenicity, tumorigenicity, reproductive or irritant effect, with the one exception of $\mathbf{4 q}$, which presents a low irritant effect. Overall, the ADME scores of bis(spiropyrazolone)cyclopropanes $\mathbf{4 - u}$ are quite satisfactory. 
Table 4. Theoretical prediction of ADME properties. Theoretical prediction of adsorption, distribution, metabolism, and excretion (ADME) properties of bis(spiropyrazolone)cyclopropanes 4, calculated using Osiris DataWarrior software.

\begin{tabular}{|c|c|c|c|c|c|c|c|c|c|c|c|c|c|}
\hline & MW & HBA & HBD & nrotb & PSA & $\mathbf{M}$ & $\mathbf{T}$ & $\mathbf{R}$ & I & cLogP & cLogS & DL & DS \\
\hline $4 b$ & 434.50 & 6 & 0 & 3 & 65.34 & $\mathrm{~N}$ & $\mathrm{~N}$ & $\mathrm{~N}$ & $\mathrm{~N}$ & 4.97 & -4.83 & 4.34 & 0.49 \\
\hline $4 c$ & 479.50 & 9 & 0 & 4 & 111.16 & $\mathrm{~N}$ & $\mathrm{~N}$ & $\mathrm{~N}$ & $\mathrm{~N}$ & 4.05 & -5.29 & -0.77 & 0.32 \\
\hline $4 d$ & 479.50 & 9 & 0 & 4 & 111.16 & $\mathrm{~N}$ & $\mathrm{~N}$ & $\mathrm{~N}$ & $\mathrm{~N}$ & 4.05 & -5.29 & -0.77 & 0.32 \\
\hline $4 e$ & 464.52 & 7 & 0 & 4 & 74.57 & $\mathrm{~N}$ & $\mathrm{~N}$ & $\mathrm{~N}$ & $\mathrm{~N}$ & 4.90 & -4.84 & 4.32 & 0.47 \\
\hline $4 f$ & 464.52 & 7 & 0 & 4 & 74.57 & $\mathrm{~N}$ & $\mathrm{~N}$ & $\mathrm{~N}$ & $\mathrm{~N}$ & 4.90 & -4.84 & 4.32 & 0.47 \\
\hline $4 k$ & 479.50 & 9 & 0 & 4 & 111.16 & $\mathrm{~N}$ & $\mathrm{~N}$ & $\mathrm{~N}$ & $\mathrm{~N}$ & 4.05 & -5.29 & -0.77 & 0.32 \\
\hline $4 p$ & 452.49 & 6 & 0 & 3 & 65.34 & $\mathrm{~N}$ & $\mathrm{~N}$ & $\mathrm{~N}$ & $\mathrm{~N}$ & 5.07 & -5.14 & 3.00 & 0.43 \\
\hline $4 q$ & 492.53 & 8 & 0 & 5 & 91.64 & $\mathrm{~N}$ & $\mathrm{~N}$ & $\mathrm{~N}$ & low & 4.88 & -4.97 & 1.92 & 0.33 \\
\hline $4 r$ & 502.50 & 6 & 0 & 4 & 65.34 & $\mathrm{~N}$ & $\mathrm{~N}$ & $\mathrm{~N}$ & $\mathrm{~N}$ & 5.82 & -5.60 & -2.85 & 0.17 \\
\hline $4 s$ & 518.49 & 7 & 0 & 5 & 74.57 & $\mathrm{~N}$ & $\mathrm{~N}$ & $\mathrm{~N}$ & $\mathrm{~N}$ & 6.07 & -5.85 & -3.73 & 0.15 \\
\hline $4 t$ & 452.49 & 6 & 0 & 3 & 65.34 & $\mathrm{~N}$ & $\mathrm{~N}$ & $\mathrm{~N}$ & $\mathrm{~N}$ & 5.07 & -5.14 & 3.00 & 0.43 \\
\hline $4 u$ & 480.59 & 6 & 0 & 4 & 90.64 & $\mathrm{~N}$ & $\mathrm{~N}$ & $\mathrm{~N}$ & $\mathrm{~N}$ & 5.44 & -5.67 & 4.45 & 0.36 \\
\hline
\end{tabular}

MW: molecular weight; HBA: number of hydrogen bond acceptors; HBD: number of hydrogen bond donors; nrotb: number of rotatable bonds; PSA: polar surface area; M: mutagenicity; T: tumorigenicity; R: reproductive effect; I: irritant effect; $\operatorname{cLog} P$ : $\log$ arithm of compound partition coefficient between n-octanol and water; cLogS: logarithm of compound aqueous solubility; DL: drug-likeness; DS: drug score. $\mathrm{N}$ : none.

We wanted to evaluate the genotoxic effect of compounds in mammal cells. Since human cancer cell lines are resistant to bis(spiropyrazolone)cyclopropanes 4 , we reasoned that no genotoxic effect should be observed after exposure to the compounds. To confirm this, we conducted an in vitro comet assay in a non-cancerous mammal cell line, CHO-K1. The viability measured by FDA/Ethidium Bromide, for all the evaluated compounds was greater than $93 \%$. Statistical analyses can be consulted in the Supplementary Materials (Statistical Analyses S3). The compounds $\mathbf{4 b}, \mathbf{4 q}, \mathbf{4 t}$, and $\mathbf{4} \mathbf{u}$ did not show differences with respect to the control of DMSO. The most significant were $4 \mathbf{k}$ and $\mathbf{4 d}$ (Figure 2).

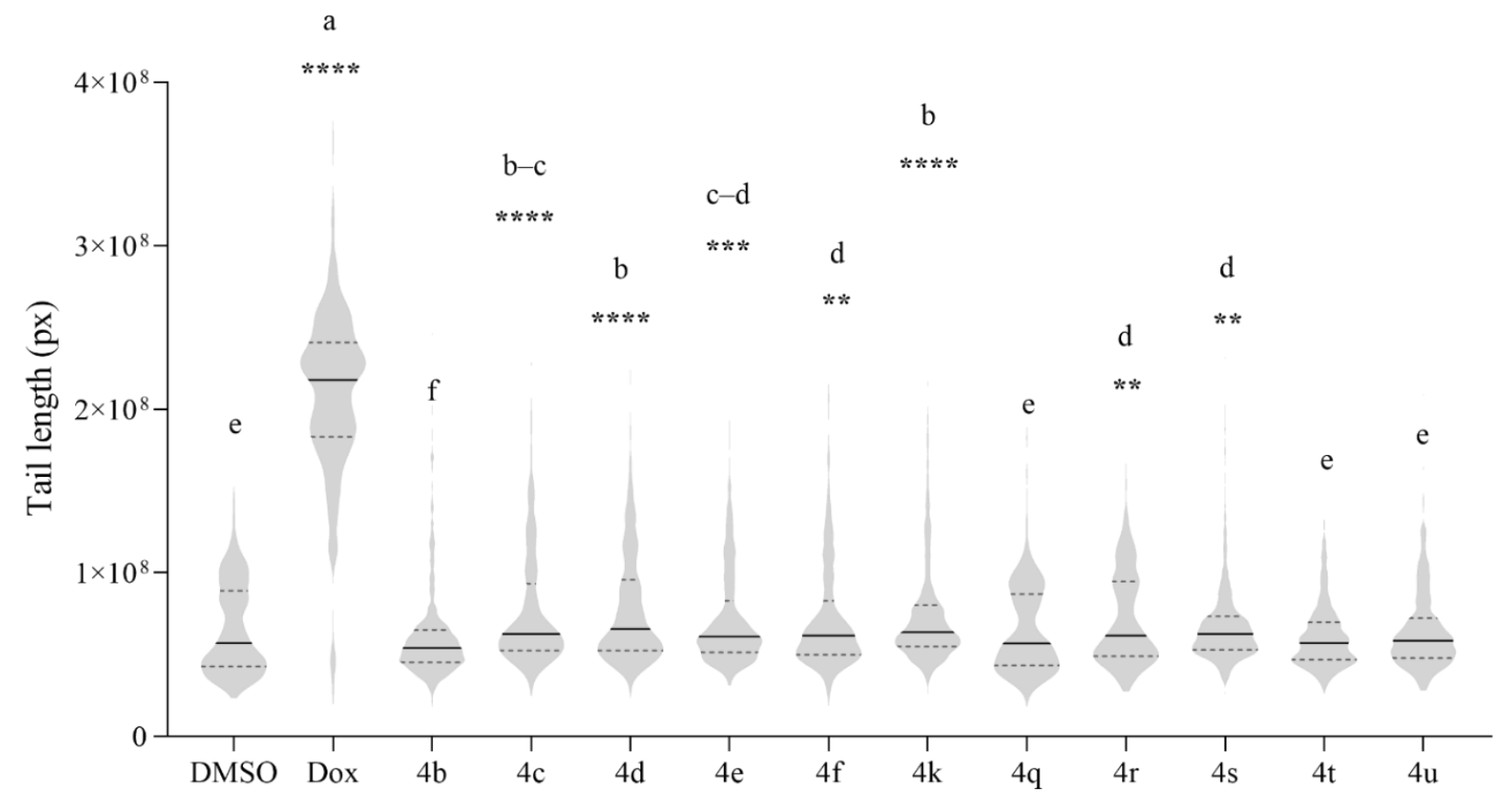

Figure 2. Comet assay of de CHO-K1 cells exposed to bis(spiropyrazolone)cyclopropanes 4. Violin plots of tail length measurements from a comet population, are represented. Black traits indicate the median and dashed traits the highest and lowest quartiles of each population. DMSO: dimethyl sulfoxide; Dox: doxorubicin. The tests for significance were limited to the Kruskal-Wallis one-way ANOVA. Post hoc tests were done by using the criterium Fisher's least significant difference. Treatments with the same letter are not significantly different. Significance codes: ${ }^{* * *} p<0.0001 ;{ }^{* * *} p<0.001 ;{ }^{* *} p<0.01$. 


\section{Discussion}

In this study, we synthesized a series of 12 bis(spiropyrazolone)cyclopropanes 4 and tested their cytotoxic properties against selected yeast, human cancer cell lines and leishmania parasites. Additionally, we evaluated their antioxidant and genotoxic properties.

The results point to a specific activity against leishmania parasites with SI values comparable to Amphotericin B, a first line drug used in leishmaniasis treatment. The results also indicate that human cancer cell lines and budding yeast are resistant to these compounds, suggesting different modes of action or different entry barriers.

Leishmaniasis is a neglected tropical disease that affects humans and some animals and is transmitted by the bite of sandflies infected with a protozoan parasite of the genus Leishmania. There are three main clinical forms of this disease depending on the parasite, immune-inflammatory responses, and the immune status of the host. Chronic infections become an acute life-threatening condition in immunocompromised individuals [45]. The disease spectrum of leishmaniasis goes from (i) a subclinical form (not apparent) or (ii) a localized (skin lesion), to (iii) a disseminated mucocutaneous and visceral form (the most important and deadly disease) [46,47].

Leishmaniasis affects the most economically vulnerable populations, and thus pharmaceutical companies have been reluctant to make important investments for the development of new treatments. This fact highlights the importance of making efforts investigating new alternatives for its treatment. An interesting approach is the use of compounds that interfere with DNA replication or metabolism that have also been frequently used as anti-tumor agents taking advantage of the characteristic of tumor cells and parasites of active replication. A comprehensive review reveals multiple differences regarding DNA repair and replication machinery between parasites of the Leishmania genus and mammalian cells [48], thus suggesting that these proteins may be potential targets for fighting leishmaniasis, which has been under-explored until now.

Leishmaniasis treatment is currently based on the use of a few drugs, mostly parenteral. These drugs are expensive with limited effectiveness. They are also long-lasting with severe adverse effects generating a high dropout rate. The medications normally used to treat visceral leishmaniasis are systemic agents such as pentavalent antimony compounds (Pentostam (Brentford, UK), Glucantime ${ }^{\circledR}$, (Paris, France), as well as Amphotericin B, pentamidine, paromomycin, and miltefosine (the only oral drug). Patients in high-income countries are treated with liposomal Amphotericin B (AmBisome ${ }^{\circledR}$, San Dimas, CA, USA). In the case of cutaneous leishmaniasis, local and/or systemic applications of the same previous drugs are used, as well as pentamidine and ketoconazole [47]. The most serious drawbacks with which health professionals must deal in the treatment of leishmaniasis with these drugs are their high toxicity, presence of severe adverse effects, generation of resistance and inconsistency in their effectiveness against different species of Leishmania parasites [49].

Our results indicate that selected cancer cell lines and yeast are not sensitive to the bis(spiropyrazolone)cyclopropanes 4 (Table S2). Yeasts are especially resistant to these compounds, even already sick double mutants, such as rad9 tof1 (Figure S2). These do not display major growth problems in the presence any of the bis(spiropyrazolone)cyclopropanes 4 . This remarkable resistance could be due to two possibilities: (i) absence of a biological target, such as an enzyme; (ii) the cell wall and/or membrane acting as natural barrier $[50,51]$. The cell wall has a sieve-like structure, and usually does not limit the transport of biomolecules. However, the cell wall can limit the entry of some compounds such as bleomycin or tetraphenylphosphonium in some cases [50,51].

The plasma membrane is the other structure that could be involved in resistance. It limits the entry of small molecules by simple diffusion and controls the entry of bigger ones by transporters and channels. Drug resistance can be developed by several microorganisms associated with ATP-binding cassettes $(\mathrm{ABC})$ transporters, efflux pumps or lipidome changes [52]. Nevertheless, this resistance is developed after exposure periods. It is possible to increase the cell wall and plasma membrane permeability with organic solvents, 
detergents, or exposure to an electric field [50,53]. In the case of the resistance observed in S. cerevisiae to the bis(spiropyrazolone)cyclopropanes 4 it is more likely to consider a preexistent natural barrier because there is no previous exposure to these compounds.

On the other hand, the assayed human cell lines also showed resistance to the bis(spiropyrazolone)cyclopropanes 4 , but in a lower order of magnitude possibly explained by the absence of cell wall (Table 2). In any case, the $\mathrm{IC}_{50}$ values are still too elevated to be exploitable in terms of anticancer therapeutics. Strikingly, the compounds showed a high activity against L. mexicana (Table 3 ). The calculated SI gives relatively good ratios. Amphotericin B was used as a control because it is a first line drug used in leishmaniasis treatment. The less active compounds are $4 \mathbf{e}$ and $4 \mathbf{f}$ with an $\mathrm{IC}_{50}$ statistically different from Amphotericin B (groups a and b, respectively). Compounds $4 r$ and $4 s$ exhibit very good leishmanicidal activity with an $\mathrm{IC}_{50}$ of $0.19 \mu \mathrm{M}$ for both. This is close to the $\mathrm{IC}_{50}$ $(0.17 \mu \mathrm{M})$ of Amphotericin B, all of them belonging to group $\mathrm{d}$. The SI ratios of $4 \mathbf{r}$ and 4s are 34.2 and 45.3, respectively. In contrast to the bis(spiropyrazolone)cyclopropanes 4 , Amphotericin B is also effective against yeasts and fungi [54]. This observation, however, cannot distinguish if this difference is due to a different mechanism of action, or to a natural resistance specific for bis(spiropyrazolone)cyclopropanes 4 . More analysis remains to be done to determine if compounds $4 \mathbf{r}$ and $\mathbf{4 s}$ can be real therapeutic agents for leishmaniasis, but preliminary results encourage us to move forward next to in vivo studies.

Compounds $4 \mathrm{~b}, \mathbf{4 c}$ and $4 \mathrm{~d}$ are also classified into group $\mathrm{d}$ and are the most active with an $\mathrm{IC}_{50}$ of $0.16 \mu \mathrm{M}$ for $4 \mathbf{b}$ and $0.15 \mu \mathrm{M}$ both for $4 \mathbf{c}$ and $4 \mathrm{~d}$. Substitution on the aromatic ring decreases the activity versus $4 \mathbf{b}$ independent of the nature of the substituent; however, no effect was observed in the case of $\mathbf{4} \mathbf{c}$ and $\mathbf{4 d}$ - these both have a nitro group at ortho and meta positions, respectively. Analysis of the substituents shows that compounds bearing electron-withdrawing groups are more active than compounds with electron-donating ones independent of their location on the ring. Nevertheless, there is not enough information to make a generalization regarding the location of the substituent and its effect on the leishmanicidal activity.

We performed comet assay analyses in leishmania cells exposed to the compounds to better understand the underlying mechanism of action of bis(spiropyrazolone)cyclopropanes 4 . This approach gives a measure of the presence of DNA damage after drug exposure. We performed the analyses in alkaline conditions, to detect DNA double-strand breaks, singlestrand breaks, and alkali-labile sites $[55,56]$. The results showed the presence of DNA damage to a greater or lesser extent after exposure to the compounds (Figure 1). The strongest effects were induced by $\mathbf{4 k}, \mathbf{4} \mathbf{q}$ and $\mathbf{4} \mathbf{u}$, while the weakest was generated by 4s. While genotoxic effect can somehow explain the mechanism of action in leishmania cells, it is undesirable if it occurs in normal mammal cell lines. To evaluate this, comet assay was performed in the CHO-K1 cell line (Figure 2). This cell line presented only $6 \%$ inhibition (Table S1), and comet assay was performed in cells with a viability of at least $93 \%$. Analyses indicate less effect in the tail length of $\mathrm{CHO}$ K-1 cells population exposed to bis(spiropyrazolone)cyclopropanes 4 (Figure 2) with respect to L. mexicana cells. In addition, theoretical prediction of adsorption, distribution, metabolism, and excretion (ADME) properties of bis(spiropyrazolone)cyclopropanes 4 returns good scores with only minor rules violation. Interestingly, no undesired effects (mutagenicity, tumorigenicity, reproductive or irritant effects) are described for these compounds, except $\mathbf{4 q}$, which has a low predicted irritant effect.

\section{Materials and Methods}

\subsection{Chemistry}

4.1.1. General

All solvents and reagents were from Aldrich (St. Louis, MO, USA) and used without further purification. All melting points are uncorrected and were determined on a Büchi Melting Point M-560 apparatus (Büchi Labortechnik AG, Flawil, Switzerland). FTIR spectra were recorded by a Perkin Elmer FTIR Spectrum One (Waltham, MA, USA) by using ATR 
system $\left(4000-650 \mathrm{~cm}^{-1}\right)$. The ${ }^{1} \mathrm{H}$ and ${ }^{13} \mathrm{C}$ NMR spectra were recorded at $298 \mathrm{~K}$ on a Varian 400/54 Premium Shielded NMR Magnet System (Yarnton, Oxford, UK USA) using $\mathrm{CDCl}_{3}$ and DMSO- $d_{6}$ as solvents. The ${ }^{19}$ F-NMR spectra were acquired on an Oxford Instruments Pulsar benchtop NMR $60 \mathrm{MHz}$ Spectrometer (Tubney Woods, Abingdon, Oxford, UK). Chemical shifts are expressed in ppm with TMS as an internal reference (TMS, $\delta=0 \mathrm{ppm}$ ) for protons and trifluoroacetic acid (TFA, $\delta=-75.39 \mathrm{ppm}$ ) for fluorine Accurate mass data was obtained using a Waters (Waltham, MA, USA) model LCT Premiere time-offlight (TOF) mass spectrometer. Reactions were monitored by TLC on silica gel using ethyl acetate/hexane mixtures as a solvent and compounds visualized by UV lamp. The reported yields are for the purified material and are not optimized.

4.1.2. General Procedure for the Synthesis of 4,4'-(Arylmethylene)bis(3-methyl-1-phenyl-1H-pyrazol-5-ols) 2a-u

All 4,4'-(arylmethylene)bis(3-methyl-1-phenyl-1H-pyrazol-5-ols) 2, except $\mathbf{2 h}$ and $\mathbf{2 m}$, were reported previously [12,57-59] and synthesized according to the reported procedures by our research group [12]. To a solution of $0.4 \mathrm{mmol}$ aldehyde $3 \mathbf{a}-\mathbf{u}$ and $0.8 \mathrm{mmol}$ pyrazol 1 in $4 \mathrm{~mL}$ of $70 \% \mathrm{EtOH}, 40.2 \mu \mathrm{L}$ of $1 \mathrm{M} \mathrm{NaOAc}$ were added and the mixture was stirred at room temperature until the reaction was complete. Water was added to obtain $50 \% \mathrm{EtOH}$ and the mixture was filtered, washed with $50 \% \mathrm{EtOH}$ and dried to obtain pure product.

4,4'-[(5-Hydroxy-2-nitrophenyl)methylene]bis(3-methyl-1-phenyl-1H-pyrazol-5-ol) (2h): yield 93\% as a slightly yellow solid; mp 205-207 ${ }^{\circ} \mathrm{C}(\mathrm{d}) ;{ }^{1} \mathrm{H}-\mathrm{NMR}\left(500 \mathrm{MHz}, \mathrm{DMSO}-d_{6}\right) \delta: 13.23$ (br. s., $1 \mathrm{H}), 10.65(\mathrm{~s}, 1 \mathrm{H}), 7.72(\mathrm{~d}, J=8.8 \mathrm{~Hz}, 1 \mathrm{H}), 7.68(\mathrm{~d}, J=7.7 \mathrm{~Hz}, 4 \mathrm{H}), 7.44(\mathrm{t}, J=7.7 \mathrm{~Hz}, 4 \mathrm{H})$, $7.24(\mathrm{t}, J=7.1 \mathrm{~Hz}, 2 \mathrm{H}), 7.06-7.01(\mathrm{~m}, 1 \mathrm{H}), 6.75(\mathrm{dd}, J=2.7,8.8 \mathrm{~Hz}, 1 \mathrm{H}), 5.61(\mathrm{~s}, 1 \mathrm{H}), 2.24(\mathrm{~s}$, $6 \mathrm{H}) ;{ }^{13} \mathrm{C}-\mathrm{NMR}\left(126 \mathrm{MHz}\right.$, DMSO-d $\left.d_{6}\right) \delta: 160.9,146.1,141.0,138.2,129.0,127.6,125.7,125.7$, 125.7, 120.5, 117.0, 113.6, 29.8, 11,6; FTIR $\left(\mathrm{cm}^{-1}\right)$ : 3615, 2924, 1595, 1498, 1349, 1258, 1070, 751, 685; HRMS (TOF ES+) $m / z$ calcd for $\mathrm{C}_{27} \mathrm{H}_{24} \mathrm{~N}_{5} \mathrm{O}_{5}(\mathrm{M}+\mathrm{H})^{+}: 498.1772$; found: 498.1777 .

4,4'-[(4-Hydroxy-3,4-dimethoxyphenyl)methylene]bis(3-methyl-1-phenyl-1H-pyrazol-5-ol) (2m): yield 97\% as a cream solid; mp 208-210 ${ }^{\circ} \mathrm{C} ;{ }^{1} \mathrm{H}-\mathrm{NMR}\left(500 \mathrm{MHz}, \mathrm{DMSO}-d_{6}\right) \delta: 14.10(\mathrm{~s}, 1 \mathrm{H})$, 12.41 (br. s., 1 H), 8.19 (br. s., $1 \mathrm{H}), 7.70(\mathrm{~d}, J=8.23 \mathrm{~Hz}, 4 \mathrm{H}), 7.44(\mathrm{t}, J=7.68 \mathrm{~Hz}, 4 \mathrm{H}), 7.24$ $(\mathrm{t}, J=7.41 \mathrm{~Hz}, 2 \mathrm{H}), 6.61(\mathrm{~s}, 2 \mathrm{H}), 4.84(\mathrm{~s}, 1 \mathrm{H}), 3.67(\mathrm{~s}, 6 \mathrm{H}), 2.32$ (br. s., $6 \mathrm{H}) ;{ }^{13} \mathrm{C}-\mathrm{NMR}$ $\left(126 \mathrm{MHz}, \mathrm{DMSO}-d_{6}\right) \delta: 147.7,146.1,134.2,132.8,128.9,125.6,120.7,105.3,56.1,33.4,11.8$; FTIR $\left(\mathrm{cm}^{-1}\right.$ ): $3225,1607,1580,1505,1454,1223,1107,762,698$; HRMS (TOF ES+) $\mathrm{m} / \mathrm{z}$ calcd for $\mathrm{C}_{29} \mathrm{H}_{29} \mathrm{~N}_{4} \mathrm{O}_{5}(\mathrm{M}+\mathrm{H})^{+}$: 513.2132; found: 513.2138.

4.1.3. Synthesis of $\left(5 R^{*}, 6 R^{*}\right)-11$-Aryl-4,10-dimethyl-2,8-diphenyl-2,3,8,9tetraazadispiro[4.0.4.1]undeca-3,9-diene-1,7-diones 4

The synthesis of the spirocyclopropanes 4 was adapted from a procedure reported by Elinson and coworkers [34]. To a 1 millimolar solution of $\mathbf{2}$ in $\mathrm{MeOH}$ was added $0.6 \mathrm{mmol}$ of $\mathrm{NaBr}$ and the mixture was electrolyzed at room temperature in an undivided cell equipped with magnetic stirrer. The electrochemical device used for the reaction was ensembled as previously reported [60], using a $6 \mathrm{~V}, 800 \mathrm{~mA}$ D.C. power supply, a $2.0 \mathrm{~mm}$ mechanical pencil lead refills as graphite anode, and an iron wire with the same diameter as cathode (electrodes surface $1.2 \mathrm{~cm}^{2}$ ). Current was passed through the reaction mixture until starting material was consumed (sometimes it is necessary to clean both electrodes to withdraw the spots of solid deposited). The progress of the reaction was monitored by TLC. When the electrolysis was finished, the mixture was gently concentrated under vacuum to one fifth of initial volume and stored at $0{ }^{\circ} \mathrm{C}$ overnight. The precipitates formed were collected by filtration, rinsed with the minimum amount of ice-cold $\mathrm{MeOH}$ and then dried in vacuum to produce the pure compounds.

(5R*,6R*)-4,10-Dimethyl-2,8,11-triphenyl-2,3,8,9-tetraazadispiro[4.0.4.1]undeca-3,9-diene-1,7-dione (4b): yield $81 \%$ as a white solid; mp $129-130{ }^{\circ} \mathrm{C}$ [Lit $166-168{ }^{\circ} \mathrm{C}$ ] [34]; ${ }^{1} \mathrm{H}-\mathrm{NMR}(400 \mathrm{MHz}$, $\left.\mathrm{CDCl}_{3}\right)$ 8: $2.09(\mathrm{~s}, 3 \mathrm{H}), 2.53(\mathrm{~s}, 3 \mathrm{H}), 4.45(\mathrm{~s}, 1 \mathrm{H}), 7.18-7.26(\mathrm{~m}, 4 \mathrm{H}), 7.36-7.47(\mathrm{~m}, 7 \mathrm{H}), 7.89$ $(\mathrm{dd}, J=8.6,1.2 \mathrm{~Hz}, 2 \mathrm{H}), 7.93(\mathrm{dd}, J=8.6,1.2 \mathrm{~Hz}, 2 \mathrm{H}),{ }^{13} \mathrm{C}-\mathrm{NMR}\left(100 \mathrm{MHz}, \mathrm{CDCl}_{3}\right) \delta: 18.5$, 
20.4 $43.2,50.4,51.4,119.1,125.6,125.7,128.1,128.7,128.9,129.0,129.1,130.0,137.9,138.0$, 155.4, 156.1, 165.7, 167.8; FTIR ( $\left.\mathrm{cm}^{-1}\right)$ : 1707, 1595, 1499, 744, 688; ESI-MS, m/z, (rel. int.): 435.10 (55.22) $[\mathrm{M}+\mathrm{H}]^{+}, 262.94$ (16.14), 174.84 (100.0).

$\left(5 R^{*}, 6 R^{*}\right)$-11-(2-Nitrophenyl)-4,10-dimethyl-2,8-diphenyl-2,3,8,9-tetraazadispiro[4.0.4.1]undeca-3,9diene-1,7-dione (4c): yield $70 \%$ as a white solid; mp $165.1-165.5{ }^{\circ} \mathrm{C} ;{ }^{1} \mathrm{H}-\mathrm{NMR}(400 \mathrm{MHz}$, $\left.\mathrm{CDCl}_{3}\right) \delta: 2.05(\mathrm{~s}, 3 \mathrm{H}), 2.58(\mathrm{~s}, 3 \mathrm{H}), 4.66(\mathrm{bs}, 1 \mathrm{H}), 7.20(\mathrm{t}, \mathrm{t}, J=7.5,1.2 \mathrm{~Hz} 1 \mathrm{H}), 7.25(\mathrm{t}, \mathrm{t}, J=7.5$, $1.2 \mathrm{~Hz} 1 \mathrm{H}), 7.35(\mathrm{ddd}, J=8.9,1.4,1.0 \mathrm{~Hz}, 1 \mathrm{H}), 7.38(\mathrm{dd}, J=8.6,7.4 \mathrm{~Hz}, 2 \mathrm{H}), 7.45(\mathrm{dd}$, $J=8.6,7.4 \mathrm{~Hz}, 2 \mathrm{H}), 7.60(\mathrm{dddd}, J=8.9,6.9,1.4,0.8 \mathrm{~Hz}, 1 \mathrm{H}), 7.68(\mathrm{ddd}, J=8.2,6.9,1.4 \mathrm{~Hz}$, $1 \mathrm{H}), 7.75(\mathrm{dd}, J=8.6,1.2 \mathrm{~Hz}, 2 \mathrm{H}), 7.94(\mathrm{dd}, J=8.6,1.2 \mathrm{~Hz}, 2 \mathrm{H}), 8.17(\mathrm{dd}, J=8.2,1.4 \mathrm{~Hz}$, $1 \mathrm{H}) ;{ }^{13} \mathrm{C}-\mathrm{NMR}\left(100 \mathrm{MHz} \mathrm{CDCl}_{3}\right) \delta: 18.3,20.3,42.1,50.5,51.2,119.2,119.6,125.1,125.6$, 125.9, 129.0, 129.2, 130.1, 133.1, 133.5, 137.7, 137.8, 149.1, 154.1, 156.4, 165.4, 165.7, 167.4; FTIR $\left(\mathrm{cm}^{-1}\right):$ 1702, 1595, 1521, 1498, 1347, 758, 689; ESI-MS, $m / z$, (rel. int.): 502.18 (100) $[\mathrm{M}+\mathrm{Na}]^{+}$.

(5R*,6R*)-11-(3-Nitrophenyl)-4,10-dimethyl-2,8-diphenyl-2,3,8,9-tetraazadispiro[4.0.4.1]undeca-3,9diene-1,7-dione (4d): yield $91 \%$ as a white solid; mp $183.9-185.0{ }^{\circ} \mathrm{C} ;{ }^{1} \mathrm{H}-\mathrm{NMR}(400 \mathrm{MHz}$, $\left.\mathrm{CDCl}_{3}\right) \delta: 2.09(\mathrm{~s}, 3 \mathrm{H}), 2.53(\mathrm{~s}, 3 \mathrm{H}), 4.45(\mathrm{~s}, 1 \mathrm{H}), 7.22(\mathrm{t}, J=7.5 \mathrm{~Hz}, 1 \mathrm{H}), 7.26(\mathrm{t}, J=7.5 \mathrm{~Hz}$, $1 \mathrm{H}), 7.41(\mathrm{dd}, J=8.6,7.5 \mathrm{~Hz}, 2 \mathrm{H}), 7.46(\mathrm{dd}, J=8.6,7.5 \mathrm{~Hz}, 2 \mathrm{H}), 7.53-7.62(\mathrm{~m}, 2 \mathrm{H}), 7.84$ $(\mathrm{dd}, J=8.4,1.2 \mathrm{~Hz}, 2 \mathrm{H}), 7.93(\mathrm{dd}, J=8.4,1.2 \mathrm{~Hz}, 2 \mathrm{H}), 8.09-8.12(\mathrm{~m}, 1 \mathrm{H}), 8.26(\mathrm{dt}, J=7.5$, $2.0 \mathrm{~Hz}, 1 \mathrm{H}) ;{ }^{13} \mathrm{C}-\mathrm{NMR}\left(100 \mathrm{MHz}, \mathrm{CDCl}_{3}\right) \delta: 18.5,20.4,41.7,49.8,50.8,119.1,119.2,123.9$, $125.2,125.9,126.0,129.1,129.2,129.8,130.6,136.1,137.7,148.3,154.1,155.6,165.3,167.2$; FTIR $\left(\mathrm{cm}^{-1}\right): 1702,1595,1532,1488,1365,845,759,691$; ESI-MS, $m / z$, (rel. int.): 480.23 (39.01) $[\mathrm{M}+\mathrm{H}]^{+}, 172.82(100)$.

$\left(5 R^{*}, 6 R^{*}\right)-11-(4-M e t h o x y p h e n y l)-4,10$-dimethyl-2,8-diphenyl-2,3,8,9-tetraazadispiro[4.0.4.1]undeca-3,9diene-1,7-dione (4e): yield $87 \%$ as a white solid; mp $163.5-165.7{ }^{\circ} \mathrm{C} ;{ }^{1} \mathrm{H}-\mathrm{NMR}(400 \mathrm{MHz}$, $\left.\mathrm{CDCl}_{3}\right) \delta: 2.10(\mathrm{~s}, 3 \mathrm{H}), 2.53(\mathrm{~s}, 3 \mathrm{H}), 3.82(\mathrm{~s}, 3 \mathrm{H}), 4.39(\mathrm{bs}, 1 \mathrm{H}), 6.90(\mathrm{~d}, J=8.8 \mathrm{~Hz}, 2 \mathrm{H}), 7.12$ $(\mathrm{dd}, J=8.8,0.8 \mathrm{~Hz}, 2 \mathrm{H}), 7.20(\mathrm{tt}, J=7.4,1.2 \mathrm{~Hz} 1 \mathrm{H}), 7.23(\mathrm{tt}, J=7.4,1.0 \mathrm{~Hz} 1 \mathrm{H}), 7.40(\mathrm{dd}$, $J=8.5,7.5 \mathrm{~Hz} 2 \mathrm{H}), 7.44(\mathrm{dd}, J=8.5,7.5 \mathrm{~Hz} 2 \mathrm{H}), 7.89(\mathrm{dd}, J=8.8,1.0 \mathrm{~Hz}, 2 \mathrm{H}), 7.93(\mathrm{dd}$, $J=8.8,1.0 \mathrm{~Hz}, 2 \mathrm{H}) ;{ }^{13} \mathrm{C}-\mathrm{NMR}\left(100 \mathrm{MHz} \mathrm{CDCl}_{3}\right) \delta: 18.3,20.2,42.7,50.4,51.5,55.2,114.0$, $118.9,119.7,125.4,125.5,128.8,128.9,131.0,137.8,137.8,155.3,156.0,159.7,165.6,167.7$; FTIR $\left(\mathrm{cm}^{-1}\right)$ : 1706, 1593, 1589, 1251, 1035, 757, 689; ESI-MS, $m / z$, (rel. int.): 465.15 (6.66) $[\mathrm{M}+\mathrm{H}]^{+}, 292.97$ (59.57), 174.85 (100.0).

$\left(5 R^{*}, 6 R^{*}\right)-11-(2-M e t h o x y p h e n y l)-4,10$-dimethyl-2,8-diphenyl-2,3,8,9-tetraazadispiro[4.0.4.1]undeca-3,9diene-1,7-dione (4f): yield $77 \%$ as a white solid; mp 147.8-149.0 ${ }^{\circ} \mathrm{C}$ [Lit $145-146{ }^{\circ} \mathrm{C}$ ] [34];

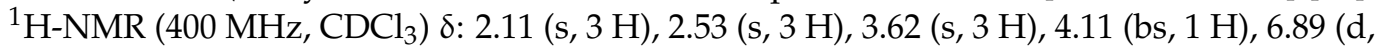
$J=8.4 \mathrm{~Hz}, 1 \mathrm{H}), 6.98(\mathrm{td}, J=7.4,0.8 \mathrm{~Hz} 1 \mathrm{H}), 7.13(\mathrm{dt}, J=7.4,1.3 \mathrm{~Hz}, 1 \mathrm{H}), 7.18(\mathrm{tt}, J=7.4$, $1.2 \mathrm{~Hz} 1 \mathrm{H}), 7.23(\mathrm{tt}, J=7.4,1.2 \mathrm{~Hz} 1 \mathrm{H}), 7.34-7.41(\mathrm{~m}, 3 \mathrm{H}), 7.44(\mathrm{dd}, J=8.6,7.4 \mathrm{~Hz} 2 \mathrm{H}), 7.87$ $(\mathrm{dd}, J=8.6,1.2 \mathrm{~Hz}, 2 \mathrm{H}), 7.94(\mathrm{dd}, J=8.6,1.2 \mathrm{~Hz}, 2 \mathrm{H}) ;{ }^{13} \mathrm{C}-\mathrm{NMR}\left(100 \mathrm{MHz}, \mathrm{CDCl}_{3}\right) \delta: 18.5$, 20.3, 39.5, 50.7, 51.1, 55.6, 110.8, 116.6, 119.0, 119.2, 120.5, 125.3, 125.6, 129.0, 129.1, 130.3, 131.2, 138.0, 138.2, 155.9, 156.4, 157.8, 166.1, 168.1. FTIR $\left(\mathrm{cm}^{-1}\right): 1708,1593,1489,1296,777$, 753; LC-MS, $m / z$, (rel. int.): 466.48 (14.86) [M + H] ${ }^{+}, 292.96$ (50.29), 174.84 (100.0).

$\left(5 R^{*}, 6 R^{*}\right)$-11-(4-Nitrophenyl)-4,10-dimethyl-2,8-diphenyl-2,3,8,9-tetraazadispiro[4.0.4.1]undeca-3,9diene-1,7-dione (4k): yield 54\% as a white solid; mp 145.3-152.9 (d) ${ }^{\circ} \mathrm{C} ;{ }^{1} \mathrm{H}-\mathrm{NMR}(400 \mathrm{MHz}$, $\left.\mathrm{CDCl}_{3}\right) \delta: 2.09(\mathrm{~s}, 3 \mathrm{H}), 2.53(\mathrm{~s}, 3 \mathrm{H}), 4.44(\mathrm{bs}, 1 \mathrm{H}), 7.22(\mathrm{tt}, J=7.4,1.2 \mathrm{~Hz}, 1 \mathrm{H}), 7.26(\mathrm{tt}$, $J=7.4,1.2 \mathrm{~Hz}, 1 \mathrm{H}), 7.40(\mathrm{dd}, J=9.0,1.1 \mathrm{~Hz}, 2 \mathrm{H}), 7.41(\mathrm{dd}, J=8.6,7.4 \mathrm{~Hz}, 2 \mathrm{H}), 7.45(\mathrm{dd}$, $J=8.6,7.4 \mathrm{~Hz}, 2 \mathrm{H}), 7.85(\mathrm{dd}, J=8.6,1.2 \mathrm{~Hz}, 2 \mathrm{H}), 7.92(\mathrm{dd}, J=8.6,1.2 \mathrm{~Hz}, 2 \mathrm{H}), 8.25(\mathrm{~d}$, $J=9.0 \mathrm{~Hz}, 2 \mathrm{H}) ;{ }^{13} \mathrm{C}-\mathrm{NMR}\left(100 \mathrm{MHz}, \mathrm{CDCl}_{3}\right) \delta: 18.5,20.5,41.9,49.9,50.8,119.1,119.1$, $123.9,125.9,126.0,129.1,129.2,131.2,135.8,137.68,137.72,148.1,154.2,155.6,165.3,167.2$; FTIR $\left(\mathrm{cm}^{-1}\right):$ 1708, 1594, 1489, 1347, 1296, 756, 688.5; LC-MS, $m / z$, (rel. int.): 502.18 (100) $[\mathrm{M}+\mathrm{Na}]^{+}$.

(5R*,6R*)-11-(4-Fluorophenyl)-4,10-dimethyl-2,8-diphenyl-2,3,8,9-tetraazadispiro[4.0.4.1]undeca-3,9diene-1,7-dione (4p): yield $47 \%$ as a white solid; mp $128.9-129.9{ }^{\circ} \mathrm{C} ;{ }^{1} \mathrm{H}-\mathrm{NMR}(400 \mathrm{MHz}$,

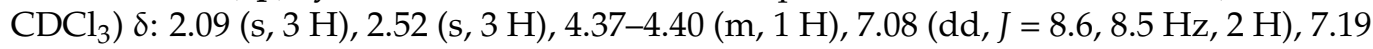


$(\mathrm{ddd}, \mathrm{J}=9.0,5.1,0.8 \mathrm{~Hz}, 2 \mathrm{H}), 7.21(\mathrm{tt}, \mathrm{J}=7.4,1.2 \mathrm{~Hz}, 1 \mathrm{H}), 7.24(\mathrm{tt}, J=7.4,1.2 \mathrm{~Hz}, 1 \mathrm{H})$, $7.41(\mathrm{dd}, J=7.5,8.6 \mathrm{~Hz}, 2 \mathrm{H}), 7.44(\mathrm{dd}, J=7.5,8.6 \mathrm{~Hz}, 2 \mathrm{H}), 7.87(\mathrm{dd}, J=8.8,1.0 \mathrm{~Hz}, 2 \mathrm{H})$, $7.92(\mathrm{dd}, J=8.6,1.2 \mathrm{~Hz}, 2 \mathrm{H}) ;{ }^{13} \mathrm{C}-\mathrm{NMR}\left(100 \mathrm{MHz}, \mathrm{CDCl}_{3}\right)$ 8: 18.5, 20.4, 42.3, 50.3, 51.4, $115.9(\mathrm{~d}, J=21.8 \mathrm{~Hz}, 2 \mathrm{C}), 119.1,123.9(\mathrm{~d}, J=3.1 \mathrm{~Hz}, 1 \mathrm{C}), 125.7,125.8,129.1,129.1,131.8(\mathrm{~d}$, $J=8.6 \mathrm{~Hz}, 2 \mathrm{C}), 137.8,137.9,155.0,156.0,162.9$ (d, $J=249.1 \mathrm{~Hz}, 1 \mathrm{C}), 165.6,167.7 ;{ }^{19} \mathrm{~F}-\mathrm{NMR}$ $\left(56.17 \mathrm{MHz} \mathrm{CDCl}_{3}\right) \delta:-112.46$ (bs); FTIR $\left(\mathrm{cm}^{-1}\right)$ : 1712, 1595, 1499, 1233, 756, 689; LC-MS, $m / z$, (rel. int.): $475.35(100)[\mathrm{M}+\mathrm{Na}]^{+}, 453.4(92.04)[\mathrm{M}+\mathrm{H}]^{+}$.

$\left(5 R^{*}, 6 R^{*}\right)$-Methyl-4[4,10-dimethyl-2,8-diphenyl-2,3,8,9-tetraazadispiro[4.0.4.1]undeca-3,9-diene-1,7dione-11-yllbenzoate (4q): yield $85 \%$ as a white solid; $\mathrm{mp} 162.5-163.9{ }^{\circ} \mathrm{C} ;{ }^{1} \mathrm{H}-\mathrm{NMR}(400 \mathrm{MHz}$, $\left.\mathrm{CDCl}_{3}\right) \delta: 2.08(\mathrm{~s}, 3 \mathrm{H}), 2.53(\mathrm{~s}, 3 \mathrm{H}), 3.93(\mathrm{~s}, 3 \mathrm{H}), 4.44(\mathrm{bs}, 1 \mathrm{H}), 7.21(\mathrm{tt}, J=7.4,1.2 \mathrm{~Hz}, 1 \mathrm{H})$, $7.24(\mathrm{tt}, J=7.4,1.2 \mathrm{~Hz}, 1 \mathrm{H}), 7.30(\mathrm{dd}, J=8.3,0.8 \mathrm{~Hz}, 2 \mathrm{H}), 7.40(\mathrm{dd}, J=8.6,7.4 \mathrm{~Hz}, 2 \mathrm{H}), 7.44$ $(\mathrm{dd}, J=8.6,7.4 \mathrm{~Hz}, 2 \mathrm{H}), 7.87(\mathrm{dd}, J=8.6,1.2 \mathrm{~Hz}, 2 \mathrm{H}), 7.93(\mathrm{dd}, J=8.6,1.2 \mathrm{~Hz}, 2 \mathrm{H}), 8.06(\mathrm{~d}$, $J=8.3 \mathrm{~Hz}, 2 \mathrm{H}) ;{ }^{13} \mathrm{C}-\mathrm{NMR}\left(100 \mathrm{MHz} \mathrm{CDCl}_{3}\right) \delta: 18.5,20.4,42.6,50.1,51.1,52.4,119.1,119.1$, $125.7,125.8,129.1,129.2,130.0,130.2,130.7,133.4,137.8,137.9,154.9,155.8,165.4,166.5$, 167.5; FTIR $\left(\mathrm{cm}^{-1}\right):$ 1709, 1595, 1494, 1279, 759, 694; LC-MS, $m / z$, (rel. int.): 515.28 (6.77) $[\mathrm{M}+\mathrm{Na}]^{+}, 493.32(100)[\mathrm{M}+\mathrm{H}]^{+}$.

$\left(5 R^{*}, 6 R^{*}\right)-11-(4-T r i f l u o r o m e t h y l p h e n y l)-4,10-$ dimethyl-2,8-diphenyl-2,3,8,9-tetraazadispiro[4.0.4.1] undeca-3,9-diene-1,7-dione (4r): yield 87\% as a white solid; mp $154.6-156.5{ }^{\circ} \mathrm{C} ;{ }^{1} \mathrm{H}-\mathrm{NMR}$ $\left(400 \mathrm{MHz}, \mathrm{CDCl}_{3}\right) \delta: 2.08(\mathrm{~s}, 3 \mathrm{H}), 2.53(\mathrm{~s}, 3 \mathrm{H}), 4.43(\mathrm{~d}, J=0.9 \mathrm{~Hz}, 1 \mathrm{H}), 7.22(\mathrm{tt}, J=7.4$, $1.2 \mathrm{~Hz}, 1 \mathrm{H}), 7.25(\mathrm{tt}, J=7.4,1.2 \mathrm{~Hz}, 1 \mathrm{H}), 7.34(\mathrm{~d}, J=8.3 \mathrm{~Hz}, 2 \mathrm{H}), 7.41(\mathrm{dd}, J=8.7,7.4 \mathrm{~Hz}$, $2 \mathrm{H}), 7.45(\mathrm{dd}, J=8.7,7.4 \mathrm{~Hz}, 2 \mathrm{H}), 7.65(\mathrm{~d}, J=8.3 \mathrm{~Hz}, 2 \mathrm{H}), 7.86(\mathrm{dd}, J=8.7,1.2 \mathrm{~Hz}, 2 \mathrm{H})$,

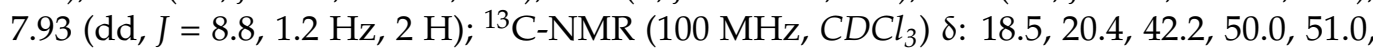
$119.1,123.9$ (q, $J=272.5 \mathrm{~Hz}, 1 \mathrm{C}), 125.7$ (q, $J=3.9 \mathrm{~Hz}, 2 \mathrm{C}), 125.8,125.9,129.1,129.2,130.5$, 131.1 (q, $J=32.7 \mathrm{~Hz}, 1 \mathrm{C}), 132.4$ (q, $J=1.2 \mathrm{~Hz}, 2 \mathrm{C}), 137.78,137.82,154.7,155.8,165.4,167.5$;

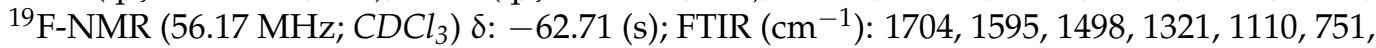
687; LC-MS, m/z, (rel. int.): 525.33 (62.46) $[\mathrm{M}+\mathrm{Na}]^{+}, 503.36(100)[\mathrm{M}+\mathrm{H}]^{+}, 413.47$ (16.18).

$\left(5 R^{*}, 6 R^{*}\right)$-11-(4-Trifluoromethoxyphenyl)-4,10-dimethyl-2,8-diphenyl-2,3,8,9-tetraazadispiro[4.0.4.1] undeca-3,9-diene-1,7-dione (4s): yield 70\% as a white solid; mp $150.5-151.5{ }^{\circ} \mathrm{C} ;{ }^{1} \mathrm{H}-\mathrm{NMR}$ $\left(400 \mathrm{MHz}_{\mathrm{CDCl}}\right)$ ) $\mathrm{CD}_{2} .08$ (s, $\left.3 \mathrm{H}\right), 2.52$ (s, $\left.3 \mathrm{H}\right), 4.39$ (bs, $\left.1 \mathrm{H}\right), 7.19-7.27$ (m, $\left.6 \mathrm{H}\right), 7.41$ (dd, $\mathrm{J}=8.6,7.4 \mathrm{~Hz}, 2 \mathrm{H}), 7.45(\mathrm{dd}, \mathrm{J}=8.6,7.4 \mathrm{~Hz}, 2 \mathrm{H}), 7.87(\mathrm{dd}, \mathrm{J}=8.8,1.2 \mathrm{~Hz}, 2 \mathrm{H}), 7.92(\mathrm{dd}$, $\mathrm{J}=8.6,1.2 \mathrm{~Hz}, 2 \mathrm{H}) ;{ }^{13} \mathrm{C}-\mathrm{NMR}\left(100 \mathrm{MHz}, \mathrm{CDCl}_{3}\right) \delta: 18.5,20.4,42.1,50.1,51.3,119.1,119.2$, $121.1,120.5$ (q, J = 257.7 Hz, 1 C), 125.75, 125.82, 126.8, 129.1, 129.2, 131.6, 137.8, 137.9, 149.5 $(\mathrm{d}, J=1.6 \mathrm{~Hz}, 1 \mathrm{C}), 154.8,155.9,165.5,167.6 ;{ }^{19} \mathrm{~F}-\mathrm{NMR}\left(56.17 \mathrm{MHz} ; \mathrm{CDCl}_{3}\right) \delta:-57.91$ (s); FTIR $\left(\mathrm{cm}^{-1}\right):$ 1705, 1594, 1498, 1254, 1222, 1166, 750, 690; LC-MS, $m / z$, (rel. int.): 541.39 (100) $[\mathrm{M}+\mathrm{Na}]^{+}, 519.46(90.66)[\mathrm{M}+\mathrm{H}]^{+}$.

$\left(5 R^{*}, 6 R^{*}\right)-11-(3-F l u o r o p h e n y l)-4,10-d i m e t h y l-2,8-d i p h e n y l-2,3,8,9-t e t r a a z a d i s p i r o[4.0 .4 .1]$ undeca-3,9diene-1,7-dione (4t): yield $84 \%$ as a white solid; mp $152.1-153.0{ }^{\circ} \mathrm{C} ;{ }^{1} \mathrm{H}-\mathrm{NMR}(400 \mathrm{MHz}$, $\left.\mathrm{CDCl}_{3}\right) \delta: 2.12(\mathrm{~s}, 3 \mathrm{H}), 2.52(\mathrm{~s}, 3 \mathrm{H}), 4.40(\mathrm{~s}, 1 \mathrm{H}), 6.94(\mathrm{dddd}, J=9.2,2.5,1.2,1.2 \mathrm{~Hz}, 1 \mathrm{H})$, 7.00 (dddd, $J=7.9,1.9,0.8,0.8 \mathrm{~Hz} 1 \mathrm{H}$ ), 7.09 (ddddd, $J=8.7,8.2,2.6,0.8,0.8 \mathrm{~Hz} 1 \mathrm{H}$ ), 7.21 $(\mathrm{tt}, J=7.4,1.2 \mathrm{~Hz}, 1 \mathrm{H}), 7.24(\mathrm{tt}, J=7.4,1.2 \mathrm{~Hz}, 1 \mathrm{H}), 7.36(\mathrm{ddd}, J=8.3,7.8,5.9 \mathrm{~Hz}, 1 \mathrm{H}), 7.41$ $(\mathrm{dd}, \mathrm{J}=8.6,7.4 \mathrm{~Hz}, 2 \mathrm{H}), 7.44(\mathrm{dd}, \mathrm{J}=8.6,7.4 \mathrm{~Hz}, 2 \mathrm{H}), 7.87(\mathrm{dd}, \mathrm{J}=8.8,1.2 \mathrm{~Hz}, 2 \mathrm{H}), 7.92$ $(\mathrm{dd}, \mathrm{J}=8.8,1.2 \mathrm{~Hz}, 2 \mathrm{H}) ;{ }^{13} \mathrm{C}-\mathrm{NMR}\left(100 \mathrm{MHz}, \mathrm{CDCl}_{3}\right) \delta: 18.3,20.2,42.2(\mathrm{~d}, \mathrm{~J}=2.3 \mathrm{~Hz}, 1 \mathrm{C})$, 50.0, 51.0, $115.8(\mathrm{~d}, J=21.1 \mathrm{~Hz}, 1 \mathrm{C}), 117.0(\mathrm{~d}, J=22.6 \mathrm{~Hz}, 1 \mathrm{C}), 118.97,118.98,125.5,125.6$, $125.6(\mathrm{~d}, J=3.1 \mathrm{~Hz}, 1 \mathrm{C}), 128.9,129.0,130.2(\mathrm{~d}, J=8.6 \mathrm{~Hz}, 1 \mathrm{C}), 130.4(\mathrm{~d}, J=8.6 \mathrm{~Hz}, 1 \mathrm{C})$, 137.66, 137.73, 154.7, 155.7, 162.5 (d, $J=248.3 \mathrm{~Hz}, 1 \mathrm{C}), 165.3,167.4 ;{ }^{19} \mathrm{~F}-\mathrm{NMR}(56.17 \mathrm{MHz}$; $\mathrm{CDCl}_{3}$ ) $\delta:-111.90$ (bs); FTIR (cm $\left.{ }^{-1}\right)$ : 1714, 1594, 1499, 1134, 751, 691; LC-MS, $m / z$, (rel. int.): $475.21(100)[\mathrm{M}+\mathrm{Na}]^{+}, 453.24(42)[\mathrm{M}+\mathrm{H}]^{+}$.

(5R*6R*)-11-(4-Thiomethylphenyl)-4,10-dimethyl-2,8-diphenyl-2,3,8,9-tetraazadispiro[4.0.4.1] undeca-3,9-diene-1,7-dione (4u): yield $64 \%$ as a white solid; mp $154.4-157.3{ }^{\circ} \mathrm{C} ;{ }^{1} \mathrm{H}-\mathrm{NMR}$ $\left(400 \mathrm{MHz}_{\mathrm{CDCl}}\right)$ ) $\mathrm{CD}_{2} 2.1$ (s, $\left.3 \mathrm{H}\right), 2.5(\mathrm{~s}, 3 \mathrm{H}), 2.5(\mathrm{~s}, 3 \mathrm{H}), 4.4$ (bs, $\left.1 \mathrm{H}\right), 7.11$ (dd, J = 8.6, $0.8 \mathrm{~Hz}, 2 \mathrm{H}), 7.21(\mathrm{tt}, J=7.4,1.2 \mathrm{~Hz}, 1 \mathrm{H}), 7.23(\mathrm{~d}, J=8.3 \mathrm{~Hz}, 2 \mathrm{H}), 7.23(\mathrm{tt}, J=7.4,1.2 \mathrm{~Hz}$, $1 \mathrm{H}), 7.40(\mathrm{dd}, J=8.6,7.4 \mathrm{~Hz}, 2 \mathrm{H}), 7.44(\mathrm{dd}, J=8.6,7.4 \mathrm{~Hz}, 2 \mathrm{H}), 7.88(\mathrm{dd}, J=8.7,1.2 \mathrm{~Hz}$, 
$2 \mathrm{H}), 7.92(\mathrm{dd}, J=8.6,1.2 \mathrm{~Hz}, 2 \mathrm{H}) ;{ }^{13} \mathrm{C}-\mathrm{NMR}\left(100 \mathrm{MHz}, \mathrm{CDCl}_{3}\right) \delta: 15.4,18.3,20.3,42.6$, 50.2, 51.3, 119.0, 124.3, 125.4, 125.6, 126.1, 128.9, 129.0, 130.2, 137.7, 137.8, 139.6, 155.1, 155.9, 165.5, 167.6; FTIR (cm $\left.{ }^{-1}\right)$ : 1715, 1596, 1498, 1365, 1130, 754, 689; LC-MS, $m / z$, (rel. int.): $503.22(100)[\mathrm{M}+\mathrm{Na}]^{+}, 481.23(7.62)$.

4-(4-(Dimethylamino)benzylidene)-3-methyl-1-phenyl-1H-pyrazol-5(4H)-one (5): yield 60\% as a red needles; mp 190.7-193.2 ${ }^{\circ} \mathrm{C}$ [Ref 192-193 ${ }^{\circ} \mathrm{C}$ ] [61]; ${ }^{1} \mathrm{H}-\mathrm{NMR}\left(400 \mathrm{MHz}, \mathrm{CDCl}_{3}\right) \delta: 2.33$ $(\mathrm{s}, 3 \mathrm{H}), 3.13(\mathrm{~s}, 6 \mathrm{H}), 6.73(\mathrm{~d}, J=9.0 \mathrm{~Hz}, 2 \mathrm{H}), 7.15(\mathrm{t}, J=7.3 \mathrm{~Hz}, 1 \mathrm{H}), 7.26(\mathrm{br} \mathrm{s}, 1 \mathrm{H}), 7.40$ (t, $J=7.8 \mathrm{~Hz}, 2 \mathrm{H}), 8.01(\mathrm{~d}, J=7.8 \mathrm{~Hz}, 2 \mathrm{H}), 8.58(\mathrm{~m}, J=9.0 \mathrm{~Hz}, 2 \mathrm{H})$.

4,10-dimethyl-2,8-diphenyl-2,3,8,9-tetraazadispiro[4.0.4 $\left.4^{6} .1^{5}\right]$ undeca-3,9-diene-1,7-dione (6): yield $4 \%$ as a white solid; mp: 165,8-167,9 ${ }^{\circ} \mathrm{C} ;{ }^{1} \mathrm{H}-\mathrm{NMR}\left(400 \mathrm{MHz}, \mathrm{CDCl}_{3}\right) \delta: 2.42(\mathrm{~s}, 6 \mathrm{H}), 2.77$ (s, $2 \mathrm{H}), 7.21(\mathrm{tt}, J=7.4,1.2 \mathrm{~Hz}, 2 \mathrm{H}), 7.41(\mathrm{dd}, J=8.6,7.4 \mathrm{~Hz}, 4 \mathrm{H}), 7.86(\mathrm{dd}, J=8.6,1.2 \mathrm{~Hz}$, $4 \mathrm{H}) ;{ }^{13} \mathrm{C}-\mathrm{NMR}\left(100 \mathrm{MHz} \mathrm{CDCl}_{3}\right) \delta: 18.3,24.8,47.4,119.2,125.7,129.1,137.9,156.3,167.7$; FTIR (cm $\left.{ }^{-1}\right)$ : 1702, 1593, 1488, 1361, 1298, 755.9, 692.2; LC-MS, $m / z$, (rel. int.): 381.16 (100) $[\mathrm{M}+\mathrm{Na}]^{+}, 359.19(8.9)[\mathrm{M}+\mathrm{H}]^{+}$.

\subsection{Biological Evaluation}

\subsubsection{Evaluation of the Fungicidal Activity on S. cerevisiae}

The antimicrobial activities of the synthesized compounds were tested against yeast S. cerevisiae (background W303), as described by Teran et al. [38]. Concentrations ranging from 2468.7 to $2.4 \mu \mathrm{M}$ were assayed.

\subsubsection{Drop Test}

The stock solutions of the compounds were prepared by dissolving $4 \mathbf{c}, 4 \mathbf{k}$ and $4 \mathbf{p}-\mathbf{u}$ in dimethyl sulfoxide (DMSO) to a concentration of $4 \mathrm{mg} / \mathrm{mL}$, and compounds $4 \mathbf{b}, 4 \mathbf{e}$, $\mathbf{4} \mathbf{d}$ and $\mathbf{4 f}$ were dissolved in EtOH. The solutions were then diluted on YPD plates to a concentration of $0.1 \mathrm{mg} / \mathrm{mL}$. DMSO 2.5\% and MMS (methyl methane sulfonate) $0.025 \%$ were used as control. Drop tests were performed as described in Teran et al. [38].

\subsubsection{Cell Culture Procedures}

Five tumor human cancer cell lines-cerebral astrocytoma (D-384), grade IV prostatic adenocarcinoma (PC-3), mammary adenocarcinoma (MCF-7), human colon carcinoma (RKO) and lung carcinoma (A-549) - along with one immortalized hamster cell line (CHO K-1) were used. The cells PC-3, MCF-7 and RKO were cultured in RPMI-1640, D-384 on DMEM and CHO K-1 on HAM F-12 medium supplemented with $10 \%$ fetal bovine serum (FBS, Invitrogen, Karlsruhe, Germany), 1\% antibiotic-antimitotic solution (100 units $/ \mathrm{mL}$ penicillin $\mathrm{G}, 100 \mu \mathrm{g} / \mathrm{mL}$ streptomycin, and $0.25 \mu \mathrm{g} / \mathrm{mL}$ amphotericin B, Gibco, Grand Island, NY, USA), and 1\% L-glutamine ( $2 \mathrm{mM}, \mathrm{Gibco})$. The cells were incubated at $37{ }^{\circ} \mathrm{C}$ in a $5 \% \mathrm{CO}_{2}$ atmosphere. The viable cells were counted using the trypan blue exclusion method in a hemocytometer [62].

4.2.4. Cell Viability Analysis and Determination of the Inhibitory Concentration $50\left(\mathrm{IC}_{50}\right)$ on Mammalian Cancer Cells Lines

The MTS (5-[3-(carboxymethoxy)phenyl]-3-(4,5-dimethyl-2-thiazolyl)-2-(4-sulfo- phenyl)$2 \mathrm{H}$-tetrazolium inner salt) cell viability assay was used to assess the inhibitory effects of the extracts on the survival of human cancer cell lines. A total of $3-5 \times 10^{3}$ cells / well were seeded into 96-well plates and were allowed to adhere for $24 \mathrm{~h}$. The cells were then treated with $50 \mu \mathrm{g} / \mathrm{mL}$ of whole extract to yield a final volume of $2 \mathrm{~mL}$. Each concentration/assay was performed three times. Dimethyl sulfoxide (DMSO) was used as a negative control at a final concentration of $0.1 \% v / v$, and $1 \mu \mathrm{M}$ Doxorubicin was used as a positive control. The cells were incubated with the treatments for $48 \mathrm{~h}$, after which $20 \mu \mathrm{L}$ MTS $(5 \mathrm{mg} / \mathrm{mL}$, Aqueous One Solution Reagent, Gibco) was added and further incubated for $4 \mathrm{~h}$ at $37^{\circ} \mathrm{C}$. The absorbance was measured at $570 \mathrm{~nm}$. The data obtained with cells treated with DMSO were defined to represent $100 \%$ viability. The $\mathrm{IC}_{50}$ was calculated in cell lines with an 
inhibition percentage over $50 \%$ for which five different doses were applied $(15,45,60,75$, 100,125 and $150 \mu \mathrm{M}$ ) using nonlinear regression [62].

\subsubsection{Cell Viability Analysis by Fluorescein Diacetate/Ethidium Bromide}

A total of $8 \times 10^{3} \mathrm{CHO}-\mathrm{K} 1$ cells were seeded in each well. After $24 \mathrm{~h}$, cells were treated with derivatives in a concentration of $100 \mu \mathrm{g} / \mathrm{mL}$. Doxorubicin $(2 \mu \mathrm{M})$ was used as positive control and DMSO $(0.25 \%)$ as the negative control. Cells were incubated for $24 \mathrm{~h}$ in a humidified incubator $\left(37^{\circ} \mathrm{C}, 5 \% \mathrm{CO}_{2}\right)$. A cellular suspension was obtained after treatment. This was centrifuged and decanted. The cells were maintained at $4{ }^{\circ} \mathrm{C}$. Cell viability was determined using fluorescein diacetate-ethidium bromide. Cells were stained in $20 \mu \mathrm{L}$ of a solution of Fluorescein diacetate $(5 \mathrm{mg} / \mathrm{mL}$ ) (FDA, Sigma Aldrich, Saint Louis, MO, USA)/Ethidium Bromide ( $0.2 \mathrm{mg} / \mathrm{mL})$ (EtBr, Promega, Madison, WI, USA) and observed under a fluorescent microscope (ZEISS-Axioskop 2 plus, filter No. 4, objective $40 \times$, Carl Zeiss, Thornwood, NY, USA). Living cells were stained in green, while dead cells exhibited red nuclei. The survival percentage was obtained by dividing the number of living cells by the total number of cells. All experiments were performed in duplicate using 200 cells per slide.

\subsubsection{Comet Assay}

Cells were mixed with $150 \mu \mathrm{L}$ low-melting-point agarose 1\% (LMP, Promega, Madison, WI, USA) and added to microscope slides previously prepared with normal-melting-point agarose 1\% (NMP, Invitrogen, Carlsbad, CA, USA). A third LMP agarose layer $(150 \mu \mathrm{L})$ was added. The slides were immersed in a cooled lysing solution ( $\mathrm{pH} 10$ ) with $10 \% \mathrm{DMSO}, 1 \%$ Triton X-100 (Sigma Aldrich, Saint Louis, MO, USA), $2.5 \mathrm{M} \mathrm{NaCl}$ (Loba Chemie, Mumbai, India), $100 \mathrm{mM}$ EDTA and $10 \mathrm{mM}$ Tris (Invitrogen, Carlsbad, CA, USA) for $12 \mathrm{~h}$ at $4{ }^{\circ} \mathrm{C}$. All steps after lysis were performed under darkness or yellow light to prevent additional DNA damage. The slides were immersed for $20 \mathrm{~min}$ in an electrophoresis buffer solution ( $\mathrm{pH}$ 13) with $\mathrm{NaOH} 300 \mathrm{mM}$ (Fisher Scientific, Waltham, MA, USA) and EDTA $1 \mathrm{mM}$ (Invitrogen, Carlsbad, CA, USA) to allow for DNA unwinding. Electrophoresis was later performed at $25 \mathrm{~V}$ and $300 \mathrm{~mA}$ for $20 \mathrm{~min}$. Slides were then sprayed with a neutralization buffer ( $\mathrm{pH} 7.5)$ $0.4 \mathrm{M}$ Tris (Sigma Aldrich, Saint Louis, MO, USA). Ethidium bromide $(60 \mu \mathrm{L})$ was added to each slide, and a cover glass was placed on the gel. The DNA migration was analyzed using a ZEISS-Axioskop 2 plus microscope with fluorescence $(40 \times)$ by scoring 100 cells per slide in duplicate. After that, the tail moment parameter was analyzed by a Comet Assay IV software (Perceptive Instruments Ltd., Bury St Edmunds, Suffolk, UK).

For leishmania, a method previously described for yeast was adapted [63]. Briefly, after incubating the cells in presence of the compounds for $24 \mathrm{~h}$, cells were collected and washed with buffer $\mathrm{S}\left(1 \mathrm{M}\right.$ sorbitol, $25 \mathrm{mM} \mathrm{KH}_{2} \mathrm{PO}_{4}$ in ultrapure water and adjust to $\mathrm{pH} 6.5$ with $\mathrm{NaOH}$ ). The pellet was resuspended in $400 \mu \mathrm{L}$ of $1.5 \% \mathrm{LMA}$ and $40 \mu \mathrm{L}$ was spread (second layer) onto previously agarose-coated slides (first layer).

Slides were immersed in cold lysis buffer $(30 \mathrm{mM} \mathrm{NaOH}, 1 \mathrm{M} \mathrm{NaCl}, 0.05 \%(w / v)$ lauroylsarcosine, $50 \mathrm{mM}$ EDTA, and $10 \mathrm{mM}$ Tris- $\mathrm{HCl}, \mathrm{pH} 10$ ) for $25 \mathrm{~min}$ and then in cold electrophoresis alkaline buffer ( $30 \mathrm{mM} \mathrm{NaOH}, 10 \mathrm{mM}$ EDTA, and $10 \mathrm{mM}$ Tris- $\mathrm{HCl}, \mathrm{pH} 10)$. They were then subjected to electrophoresis at $26 \mathrm{~V}$ and $300 \mathrm{~mA}$. Slides were immersed in neutralization buffer $\left(10 \mathrm{mM}\right.$ Tris- $\mathrm{HCl}, \mathrm{pH}$ 7.4; prepared in advance and stored at $\left.4{ }^{\circ} \mathrm{C}\right)$ for $10 \mathrm{~min}$ at room temperature. The cells were then treated with proteinase $\mathrm{K}\left(20 \mathrm{~min}, 37^{\circ} \mathrm{C}\right.$ in humid chamber), followed by a new neutralization step. To dehydrate the slides, they were immersed in $\mathrm{EtOH} 90 \%$ and $\mathrm{EtOH}$ absolute for 10 min each. Finally, the slides were stained with Sybr Gold 1X.

The DNA migration was analyzed using a LEICA microscope with fluorescence $(40 \times)$ by scoring 100 cells per slide in duplicate. The tail moment parameter was then analyzed by the Comet Score software. 


\subsubsection{Statistical Analyses}

Data were plotted with the statistical software GraphPad Prism 7.02 (GraphPad Software, Corp., San Diego, CA, USA). Kruskal-Wallis test and Tukey's post-hoc test were run by using agricolae pack-age in $\mathrm{R}$ environment.

\subsubsection{DPPH Radical Scavenging Assay}

The stock solution of the compounds was prepared by dissolving 4 in dimethyl sulfoxide (DMSO) to a concentration of $4 \mathrm{mg} / \mathrm{mL}$. The solution was diluted with methanol until a concentration of $400 \mu \mathrm{g} / \mathrm{mL}$ was obtained and then used immediately.

The experimental procedure was adapted from the literature [64]. Briefly, $100 \mu \mathrm{L}$ of a $0.2 \mathrm{mM}$ methanol solution of DPPH (2, 2-diphenyl-1-picrylhydrazyl) radical were added to $100 \mu \mathrm{L}$ of methanolic solutions of 4 prepared as serial two-fold dilutions from the stock solution in 96-well microfilter plates. Standards and edaravone were also prepared in the same concentrations. The mixture was incubated in dark at room temperature for $30 \mathrm{~min}$ and the absorbance was read at $515 \mathrm{~nm}$ on a Cytation 5 (BioTek) spectrophotometer.

The \% DPPH scavenging activity was then calculated by using the following formula:

$$
\% \text { DPPH scavenging }=100 \times\left[\frac{\left(\mathrm{A}_{\text {sample }+\mathrm{DPPH}}-\mathrm{A}_{\text {sample blank }}\right)}{\left(\mathrm{A}_{\mathrm{DPPH}}-\mathrm{A}_{\text {solvent }}\right)}\right]
$$

The antioxidant activity of the compound was expressed as $\mathrm{IC}_{50}$, which is defined as the concentration that could scavenge $50 \%$ of the $\mathrm{DPPH}$ free radical. The $\mathrm{IC}_{50}$ values were calculated in GraphPad Prism 7.02 (GraphPad Software, Corp.) The results are given as a mean \pm standard deviation (SD) of experiments done in triplicate.

\subsubsection{Evaluation of Leishmanicidal Activity}

The leishmanicidal activity of all compounds was evaluated by measuring promastigotes' mitochondrial activity using MTT colorimetric assay as described previously [65]. In this study, promastigotes from Leishmania mexicana were used. The species were confirmed by amplifying and sequencing cytochrome $b$ gene [66]. Promastigotes were cultured at $25^{\circ} \mathrm{C}$ in Schneider's Drosophila Medium (Gibco, Invitrogen, Carlsbad, CA, USA) supplemented with $10 \%$ fetal bovine serum (Eurobio, Les Ulis, France). The medium was renewed every third day. Parasite density was determined by counting the cells using a Neubauer chamber.

Into each well of a 96-well plate were dispensed $1 \times 10^{6}$ parasites/well. A stock solution of the compounds was prepared in DMSO (Sigma Aldrich, Saint Louis, MO, USA), and serial dilutions were added to the parasite suspension, leading to concentrations ranging from 100 to $0.001 \mu \mathrm{M}$, keeping the solvent concentration at $0.5 \%$. The final volume was $200 \mu \mathrm{L}$ for each well and triplicate conditions were carried out. Amphotericin B (Gibco) treatment $(1 \mu \mathrm{M})$ untreated parasites and DMSO $0.5 \%$ were used as positive and negative controls, respectively. After exposure to the compounds for $48 \mathrm{~h}$ in culture medium, $20 \mu \mathrm{L}$ of a solution of $5 \mathrm{mg} / \mathrm{mL}$ MTT dissolved in PBS were added to each well. The plate was incubated at $25^{\circ} \mathrm{C}$ for $2 \mathrm{~h}$ in darkness. The plate was then centrifuged at $4400 \mathrm{rpm}$ for $10 \mathrm{~min}$ and the culture medium was then aspirated; $50 \mu \mathrm{L}$ of DMSO were added into each well to solubilize the formazan crystals and the plate was shaken for $5 \mathrm{~min}$ and then it was measured by recording changes in absorbance at $570 \mathrm{~nm}$ using a microplate reader Cytation 5 (BioTek) spectrophotometer. A reference wavelength of $630 \mathrm{~nm}$ was used as background subtraction. Optical densities were analyzed because the quantity of formazan is directly proportional to the number of viable parasites. Data were analyzed with the statistical software GraphPad Prism 7.02 (GraphPad Software, Corp.).

\subsubsection{Evaluation of the Cell Viability}

Raw 264.7 (ATCC ${ }^{\circledR}$ TIB-71 ${ }^{\mathrm{TM}}$ ) was maintained in Dulbecco's Modified Eagle Medium (DMEM) (Gibco, Invitrogen, Gibco, Carlsbad, CA, USA) supplemented with 10\% fetal 
bovine serum (FBS) (Eurobio, Les Ulis, France) and $100 \mathrm{IU} / \mathrm{mL}$ penicillin $+100 \mu \mathrm{g} / \mathrm{mL}$ streptomycin (Gibco), at $37^{\circ} \mathrm{C}$ in a $5 \% \mathrm{CO}_{2}$ atmosphere. The medium was renewed once a week. The viability was determined using MTT (Thiazolyl Blue Tetrazolium Bromide) dye assay as described before for leishmanicidal activity assessment, with some variations. Here, $5 \times 10^{4}$ cells/well in a final volume of $100 \mu \mathrm{L}$ were deposited into a 96-well plate, in triplicate. Saponin $(2.4 \mathrm{mg} / \mathrm{mL})$ and untreated cells were used as positive control and negative control, respectively. A stock solution was prepared in DMSO and immediately diluted in media to obtain different serial concentrations (100-0.01 $\mu \mathrm{M})$. After $48 \mathrm{~h}$ exposure to the compounds, $10 \mu \mathrm{L} /$ well of MTT ( $5 \mathrm{mg} / \mathrm{mL}$ MTT in PBS) were added, and the plate was incubated at $37^{\circ} \mathrm{C}$ for $2 \mathrm{~h}$ in the dark. Cells were pelleted by centrifugation at $4400 \mathrm{rpm}$ for $10 \mathrm{~min}$ and the media was removed. Then, $100 \mu \mathrm{L} /$ well of DMSO were added and the absorbance at $570 \mathrm{~nm}$ was recorded; a reference wavelength of $630 \mathrm{~nm}$ was used for background subtraction.

\section{Conclusions}

In summary, our results indicate that leishmania are sensitive to most of the bis(spiropyrazolone)cyclopropanes species reported, but no major effect is observed in yeast or human cancer cell lines. Our results suggest the good activity of bis(spiropyrazolone)cyclopropanes 4 against $L$. mexicana with $4 r-s$ being the most promising. These two compounds show a high leishmanicidal activity $\left(\mathrm{IC}_{50} 0.19 \mu \mathrm{M}\right)$ with reasonable SI ratios (34.2 and 45.3, respectively). They have fewer genotoxic effect in vitro when exposed to mammalian cell lines. At least some of the compounds studied, but not all, can exert activity by inducing DNA damage. Our data do not allow us to distinguish if DNA damage is exerted directly by the bis(spiropyrazolone)cyclopropanes 4 , or indirectly through inhibition of an enzymatic activity.

This work constitutes the first in vitro screening and unveils compounds with a potential application or, on the contrary, little or no promise. However, additional studies are needed to uncover the real uses and applications of these compounds in therapy before a drug can reach the clinic.

Supplementary Materials: The following are available online. Figure S1. Cell morphology of RKO, PC-3 and HeLa cell lines exposed to the inhibitory concentration $\left(\mathrm{IC}_{50}\right)$ of the most active bis(spiropyrazolone) cyclopropanes 4 for 48 h, Figure S2. Drop test for S. cerevisiae strains in presence of bis (spiropyrazolone) cyclopropanes 4, Figure S3. Stability of bis (spiropyrazolone) cyclopropanes 4, Figure S4. Representative examples of Leishmania mexicana cells exposed to bis(spiropyrazolone)cyclopropanes 4 and subjected to comet assay. Figure S5. ${ }^{1} \mathrm{H}$ NMR spectrum of compound 2a, Figure S6. ${ }^{1} \mathrm{H}$ NMR spectrum of compound $\mathbf{2 b}$, Figure S7. ${ }^{1} \mathrm{H}$ NMR spectrum of compound $2 \mathbf{c}$, Figure S8. ${ }^{1} \mathrm{H}$ NMR spectrum of compound 2d, Figure S9. ${ }^{1} \mathrm{H}$ NMR spectrum of compound 2e, Figure S10. ${ }^{1} \mathrm{H}$ NMR spectrum of compound 2f, Figure S11. ${ }^{1} \mathrm{H}$ NMR spectrum of compound 2g, Figure S12. ${ }^{1} \mathrm{H}$ NMR spectrum of compound $2 \mathbf{h}$, Figure S13. ${ }^{13} \mathrm{C}$ NMR spectrum of compound $2 \mathbf{h}$, Figure S14. FTIR spectrum of compound $\mathbf{2 h}$, Figure S15. HRMS spectrum of compound $\mathbf{2 h}$, Figure S16. ${ }^{1} \mathrm{H}$ NMR spectrum of compound 2i, Figure S17. ${ }^{1} \mathrm{H}$ NMR spectrum of compound 2j, Figure S18. ${ }^{1} \mathrm{H}$ NMR spectrum of compound 2k, Figure S19. ${ }^{1} \mathrm{H}$ NMR spectrum of compound 21, Figure S20. ${ }^{1} \mathrm{H}$ NMR spectrum of compound $2 \mathrm{~m}$, Figure S21. ${ }^{13} \mathrm{C}$ NMR spectrum of compound $2 \mathrm{~m}$, Figure S22. FTIR spectrum of compound $2 \mathrm{~m}$, Figure S23. HRMS spectrum of compound $2 \mathbf{m}$, Figure S24. ${ }^{1} \mathrm{H}$ NMR spectrum of compound $\mathbf{2 n}$, Figure S25. ${ }^{1} \mathrm{H}$ NMR spectrum of compound 2o, Figure S26. ${ }^{1} \mathrm{H}$ NMR spectrum of compound $2 \mathbf{p}$, Figure S27. ${ }^{19} \mathrm{~F}$ NMR spectrum of compound $\mathbf{2 p}$, Figure S28. ${ }^{1} \mathrm{H}$ NMR spectrum of compound $\mathbf{2 q}$, Figure S29. ${ }^{1} \mathrm{H}$ NMR spectrum of compound $2 \mathbf{r}$, Figure S30. ${ }^{1} \mathrm{H}$ NMR spectrum of compound $2 \mathbf{s}$, Figure S31. ${ }^{1} \mathrm{H}$ NMR spectrum of compound $2 \mathbf{t}$, Figure S32. ${ }^{1} \mathrm{H}$ NMR spectrum of compound $\mathbf{2 u}$, Figure S33. ${ }^{1} \mathrm{H}$ NMR spectrum of compound $4 \mathbf{b}$, Figure S34. ${ }^{13} \mathrm{C}$ NMR spectrum of compound $4 \mathbf{b}$, Figure S35. FTIR spectrum of compound $\mathbf{4} \mathbf{b}$, Figure S36. ESI-MS spectrum of compound $\mathbf{4 b}$, Figure S37. ${ }^{1} \mathrm{H}$ NMR spectrum of compound 4c, Figure S38. ${ }^{13} \mathrm{C}$ NMR spectrum of compound 4c, Figure S39. FTIR spectrum of compound 4c, Figure S40. ESI-MS spectrum of compound 4c, Figure S41. ${ }^{1} \mathrm{H}$ NMR spectrum of compound 4d, Figure $S 42 .{ }^{13} \mathrm{C}$ NMR spectrum of compound 4d, Figure S43. FTIR spectrum of compound 4d, Figure S44. ESI-MS spectrum of compound $4 \mathrm{~d}$, Figure S45. ${ }^{1} \mathrm{H}$ NMR spectrum of compound 4e, Figure S46. ${ }^{13} \mathrm{C}$ NMR spectrum of compound 4e, Figure S47. FTIR 
spectrum of compound 4e, Figure S48. ESI-MS spectrum of compound 4e, Figure S49. ${ }^{1} \mathrm{H}$ NMR spectrum of compound 4f, Figure S50. ${ }^{13} \mathrm{C}$ NMR spectrum of compound $4 \mathbf{f}$, Figure S51. ${ }^{1} \mathrm{H}$ NMR spectrum of compound $4 \mathbf{k}$, Figure S52. ${ }^{13} \mathrm{C}$ NMR spectrum of compound $4 \mathbf{k}$, Figure S53. FTIR spectrum of compound 4k, Figure S54. ESI-MS spectrum of compound 4k, Figure S55. ${ }^{1} \mathrm{H}$ NMR spectrum of compound $4 \mathrm{p}$, Figure S56. ${ }^{13} \mathrm{C}$ NMR spectrum of compound $4 \mathrm{p}$, Figure S57. ${ }^{19} \mathrm{~F}$ NMR spectrum of compound $4 \mathbf{p}$, Figure S58. FTIR spectrum of compound $4 \mathbf{p}$, Figure S59. ESI-MS spectrum of compound 4p, Figure S60. ${ }^{1} \mathrm{H}$ NMR spectrum of compound 4q, Figure S61. ${ }^{13} \mathrm{C}$ NMR spectrum of compound $\mathbf{4 q}$, Figure S62. FTIR spectrum of compound $\mathbf{4 q}$, Figure S63. ESI-MS spectrum of compound 4q, Figure S64. ${ }^{1} \mathrm{H}$ NMR spectrum of compound 4r, Figure S65. ${ }^{13} \mathrm{C}$ NMR spectrum of compound 4r, Figure S66. ${ }^{19}$ F NMR spectrum of compound 4r, Figure S67. FTIR spectrum of compound 4r, Figure S68. ESI-MS spectrum of compound 4r, Figure S69. ${ }^{1} \mathrm{H}$ NMR spectrum of compound $4 \mathbf{s}$, Figure S70. ${ }^{13} \mathrm{C}$ NMR spectrum of compound 4s, Figure S71. ${ }^{19} \mathrm{~F}$ NMR spectrum of compound $4 \mathbf{s}$, Figure S72. FTIR spectrum of compound 4s, Figure S73. ESI-MS spectrum of compound 4s, Figure S74. ${ }^{1} \mathrm{H}$ NMR spectrum of compound $4 \mathbf{t}$, Figure S75. ${ }^{13} \mathrm{C}$ NMR spectrum of compound $4 \mathbf{t}$, Figure S76. ${ }^{19} \mathrm{~F}$ NMR spectrum of compound $\mathbf{4 t}$, Figure S77. FTIR spectrum of compound $\mathbf{4 t}$, Figure S78. ESI-MS spectrum of compound $4 \mathbf{t}$, Figure S79. ${ }^{1} \mathrm{H}$ NMR spectrum of compound $4 \mathbf{u}$, Figure S80. ${ }^{13} \mathrm{C}$ NMR spectrum of compound $4 \mathbf{u}$, Figure S81. FTIR spectrum of compound $4 \mathbf{u}$, Figure S82. ESI-MS spectrum of compound $4 \mathbf{u}$, Figure S83. ${ }^{1} \mathrm{H}$ NMR spectrum of compound $5 \mathrm{~g}$, Figure S84. ${ }^{1} \mathrm{H}$ NMR spectrum of compound 6, Figure S85. ${ }^{13} \mathrm{C}$ NMR spectrum of compound 6, Figure S86. DEPT spectrum of compound 6, Figure S87. HSQC spectrum of compound 6, Figure S88. HMBC spectrum of compound 6, Figure S89. FTIR spectrum of compound 6, Figure S90. ESI-MS spectrum of compound 6, Table S1. Percentage (\%) of inhibition of five human cancer cell lines, and immortalized cell CHO K-1 exposed $48 \mathrm{~h}$ to $100 \mu \mathrm{M}$ of each bis(spiropyrazolone)cyclopropanes 4 , Table S2. Inhibitory activity of bis(spiropyrazolone)cyclopropanes 4 against $S$. cerevisiae (W303 background) Table S3. DPPH scavenging activity of bis(spiropyrazolone)cyclopropanes 4, Statistical Analyses S1. Test for statistical significance were based on one-way ANOVA test applied to leishmanicidal and cytotoxicity activities of bis(spiropyrazolone)cyclopropanes 4 (Table 3). Statistical Analyses S2. Kruskal Wallis test's applied to comet assay of Leishmania mexicana cells exposed to bis(spiropyrazolone)cyclopropanes 4, Statistical Analyses S3. Kruskal Wallis test's applied to comet assay of $\mathrm{CHO}$ cells exposed to bis(spiropyrazolone)cyclopropanes 4.

Author Contributions: Conceptualization, A.P., J.C.R.-B. and J.H.-M.; formal analysis, J.S.-A., L.R.-G., N.B.-M. and J.H.-M.; funding acquisition, A.P., J.C.R.-B. and J.H.-M.; investigation, O.B.-C., G.M.-N., E.L.-B., P.R.-S., A.H., C.C. and J.H.-M.; methodology, N.B.-M., J.C.R.-B., J.S.-A., A.P. and J.H.-M.; project administration, A.P., J.C.R.-B. and J.H.-M.; supervision, E.L.-B., J.S.-A., A.P., J.C.R.-B. and J.H.-M.; writing-original draft, A.P., N.B.-M., J.C.R.-B. and J.H.-M.; writing-review and editing A.P., N.B.-M., J.C.R.-B. and J.H.-M. All authors have read and agreed to the published version of the manuscript.

Funding: This work was supported by Corporación Ecuatoriana para el Desarrollo de la Investigación y la Academia (CEDIA), Cuenca, Ecuador (CEPRA XI-2017-10), Universidad UTE, Universidad Central del Ecuador (Dirección General de Investigación y Proyectos-DGIP, Project \#6), SENPLADES (9175.0000.0000.377784 and 91750000.0000.375239, managed by Dirección General de Investigación y Proyectos, DGIP, from UCE), Académie de Recherche et d'Enseignement Supérieur (ARES) in Belgium and Universidad Técnica Particular de Loja (PROY_INV_QUI_2017_2222).

Institutional Review Board Statement: Not applicable.

Informed Consent Statement: Not applicable.

Data Availability Statement: The data presented in this study are openly available in https:/ / doi. org/10.5281/zenodo.5126826 (accessed on 4 August 2021).

Acknowledgments: The authors express their sincere thanks to Corporación Ecuatoriana para el Desarrollo de la Investigación y Academia, CEDIA, for funding and supporting the research, development and innovation through CEPRA projects, especially for project CEPRA-XI -2017-10. We also thank Ilya Raskin (Rutgers University, USA) for the kind donation of RAW 264.7 macrophages; Marbel Torres (Universidad de las Fuerzas Armadas-ESPE, Ecuador) and Jorge Arévalo (Universidad Cayetano-Heredia, Perú) for the kind donation of L. mexicana strain; and Kenneth L. Kirk (NIDDK$\mathrm{NIH})$ for his helpful comments on this manuscript. 
Conflicts of Interest: The authors declare no conflict of interest. The funders had no role in the design of the study; in the collection, analyses, or interpretation of data; in the writing of the manuscript; or in the decision to publish the results.

Sample Availability: Samples of the compounds are available from the authors.

\section{References}

1. Gomtsyan, A. Heterocycles in drugs and drug discovery. Chem. Heterocycl. Compd. 2012, 48, 7-10. [CrossRef]

2. Jamwal, A.; Javed, A.; Bhardwaj, V. A review on Pyrazole derivatives of pharmacological potential. J. Pharm. Biosci. 2013, 3, 114-123.

3. Dewangan, D.; Kumar, T.; Alexander, A.; Nagori, K.; Tripathi, D.K. Pyrazole: Their Chemistry and Pharmacological Potentials: A Review. Curr. Pharma Res. 2011, 1, 369-377.

4. Pavlov, P.T.; Goleneva, A.F.; Lesnov, A.E.; Prokhorova, T.S. Biological Activity of Some Pyrazolone Derivatives. Pharm. Chem. J. 1998, 32, 370-372. [CrossRef]

5. Naim, M.J.; Alam, O.; Nawaz, F.; Alam, J.; Alam, P. Current status of pyrazole and its biological activities. J. Pharm. Bioallied Sci. 2016, 8, 2-17. [CrossRef]

6. Higashi, Y.; Jitsuiki, D.; Chayama, K.; Yoshizumi, M. Edaravone (3-methyl-1-phenyl-2-pyrazolin-5-one), a novel free radical scavenger, for treatment of cardiovascular diseases. Recent Pat. Cardiovasc. Drug Discov. 2006, 1, 85-93. [CrossRef] [PubMed]

7. Niknam, K.; Mirzaee, S. Silica Sulfuric Acid, an Efficient and Recyclable Solid Acid Catalyst for the Synthesis of 4,4'(Arylmethylene)bis(1H-pyrazol-5-ols). Synth. Commun. 2011, 41, 2403-2413. [CrossRef]

8. Torrence, P.F.; Fan, X.; Zhang, X.; Loiseau, P.M. Structurally diverse 5-substituted pyrimidine nucleosides as inhibitors of Leishmania donovani promastigotes in vitro. Bioorg. Med. Chem. Lett. 2006, 16, 5047-5051. [CrossRef]

9. Gehrke, S.S. Small Molecules with Anti-Trypanosomal and Anti-Leishmanial Activity; University of East Anglia: Norwich, UK, 2012.

10. Sharma, G.; Chowdhury, S.; Sinha, S.; Majumder, H.K.; Kumar, S.V. Antileishmanial activity evaluation of bis-lawsone analogs and DNA topoisomerase-I inhibition studies. J. Enzyme Inhib. Med. Chem. 2014, 29, 185-189. [CrossRef] [PubMed]

11. Bharate, S.B.; Bharate, J.B.; Khan, S.I.; Tekwani, B.L.; Jacob, M.R.; Mudududdla, R.; Yadav, R.R.; Singh, B.B.; Sharma, P.R.; Maity, S.; et al. Discovery of 3,3'-diindolylmethanes as potent antileishmanial agents. Eur. J. Med. Chem. 2013, 63, 435-443. [CrossRef] [PubMed]

12. Cadena-Cruz, J.E.; Guamán-Ortiz, L.M.; Romero-Benavides, J.C.; Bailon-Moscoso, N.; Murillo-Sotomayor, K.E.; Ortiz-Guamán, N.V.; Heredia-Moya, J. Synthesis of 4,4'-(arylmethylene)bis(3-methyl-1-phenyl-1H-pyrazol-5-ols) and evaluation of their antioxidant and anticancer activities. BMC Chem. 2021, 15, 1-12. [CrossRef]

13. Ajay Kumar, K. Brief review on cyclopropane analogs: Synthesis and their pharmacological applications. Int. J. Pharm. Pharm. Sci. 2013, 5, 454-459.

14. Salaün, J.; Bird, M.S. Biologically active cyclopropanes and cyclopropenes. Curr. Med. Chem. 1995, 2, 511-542.

15. Matsui, K.; Matsui, K.; Kan, Y.; Kikuchi, J.; Matsushima, K.; Takemura, M.; Maki, H.; Kozono, I.; Ueda, T.; Minagawa, K. Stalobacin: Discovery of Novel Lipopeptide Antibiotics with Potent Antibacterial Activity against Multidrug-Resistant Bacteria. J. Med. Chem. 2020, 63, 6090-6095. [CrossRef] [PubMed]

16. Lu, J.-F.; Huang, P.; Zhang, D.; Wang, Q.; Zheng, N.; Wu, R.; Liu, Q.; Jin, L.-X.; Yu, X.-H.; Ji, X.-H.; et al. 1-(3-Amino-4-morpholino1H-indazole-1-carbonyl)-N-phenylcyclopropane-1-carboxamide: Design, synthesis, crystal structure, antitumor activity, DFT and Hirshfeld surface analysis. J. Mol. Struct. 2020, 1210, 127996. [CrossRef]

17. Arita, T.; Asano, M.; Kubota, K.; Domon, Y.; Machinaga, N.; Shimada, K. Discovery of DS34942424: An orally potent analgesic without mu opioid receptor agonist activity. Bioorg. Med. Chem. 2020, 28, 115714. [CrossRef]

18. Fioravanti, R.; Romanelli, A.; Mautone, N.; Di Bello, E.; Rovere, A.; Corinti, D.; Zwergel, C.; Valente, S.; Rotili, D.; Botrugno, O.A.; et al. Tranylcypromine-Based LSD1 Inhibitors: Structure-Activity Relationships, Antiproliferative Effects in Leukemia, and Gene Target Modulation. ChemMedChem 2020, 15, 643-658. [CrossRef]

19. Qian, P.; Du, B.; Song, R.; Wu, X.; Mei, H.; Han, J.; Pan, Y. N-Iodosuccinimide-Initiated Spirocyclopropanation of Styrenes with 1,3-Dicarbonyl Compound for the Synthesis of Spirocyclopropanes. J. Org. Chem. 2016, 81, 6546-6553. [CrossRef]

20. Schobert, R.; Knauer, S.; Seibt, S.; Biersack, B. Anticancer active illudins: Recent developments of a potent alkylating compound class. Curr. Med. Chem. 2011, 18, 790-807. [CrossRef]

21. Revesz, L.; Schlapbach, A.; Aichholz, R.; Dawson, J.; Feifel, R.; Hawtin, S.; Littlewood-Evans, A.; Koch, G.; Kroemer, M.; Möbitz, H.; et al. In vivo and in vitro SAR of tetracyclic MAPKAP-K2 (MK2) inhibitors. Part II. Bioorg. Med. Chem. Lett. 2010, 20, 4719-4723. [CrossRef]

22. Bose, G.; Bracht, K.; Bednarski, P.J.; Lalk, M.; Langer, P. Synthesis, reactions and structure-activity relationships of 1hydroxyspiro[2.5]cyclooct-4-en-3-ones: Illudin analogs with in vitro cytotoxic activity. Bioorg. Med. Chem. 2006, 14, $4694-4703$. [CrossRef] [PubMed]

23. Nord, C.; Menkis, A.; Broberg, A. Cytotoxic Illudane Sesquiterpenes from the Fungus Granulobasidium vellereum (Ellis and Cragin) Jülich. J. Nat. Prod. 2015, 78, 2559-2564. [CrossRef]

24. Richter, R.; Von Reuß, S.H.; König, W.A. Spirocyclopropane-type sesquiterpene hydrocarbons from Schinus terebinthifolius Raddi. Phytochemistry 2010, 71, 1371-1374. [CrossRef] 
25. Xiao, H.X.; Yan, Q.X.; He, Z.H.; Zou, Z.B.; Le, Q.Q.; Chen, T.T.; Cai, B.; Yang, X.W.; Luo, S.L. Total synthesis and anti-inflammatory bioactivity of (-)-majusculoic acid and its derivatives. Mar. Drugs 2021, 19, 288. [CrossRef] [PubMed]

26. Lei, Z.; Zou, G.; Gao, Y.; Yao, Y.; Peng, C.; Shu, J.; Yang, M. A new triterpenoid and a new flavonoid glycoside isolated from Bupleurum marginatum and their anti-inflammatory activity. Nat. Prod. Res. 2020, 34, 3492-3498. [CrossRef] [PubMed]

27. Köllmann, C.; Wiechert, S.M.; Jones, P.G.; Pietschmann, T.; Werz, D.B. Synthesis of $4^{\prime} / 5^{\prime}$-Spirocyclopropanated Uridine and d -Xylouridine Derivatives and Their Activity against the Human Respiratory Syncytial Virus. Org. Lett. 2019, 21, 6966-6971. [CrossRef]

28. Shi, W.; Jiang, Z.; He, H.; Xiao, F.; Lin, F.; Sun, Y.; Hou, L.; Shen, L.; Han, L.; Zeng, M.; et al. Discovery of 3,3'-Spiro[Azetidine]-2oxo-indoline Derivatives as Fusion Inhibitors for Treatment of RSV Infection. ACS Med. Chem. Lett. 2018, 9, 94-97. [CrossRef]

29. Ghosh, A.K.; Reddy, G.C.; Kovela, S.; Relitti, N.; Urabe, V.K.; Prichard, B.E.; Jurica, M.S. Enantioselective Synthesis of a Cyclopropane Derivative of Spliceostatin A and Evaluation of Bioactivity. Org. Lett. 2018, 20, 7293-7297. [CrossRef]

30. Laroche, C.; Behr, J.-B.; Szymoniak, J.; Bertus, P.; Schütz, C.; Vogel, P.; Plantier-Royon, R. Spirocyclopropyl pyrrolidines as a new series of alpha-L-fucosidase inhibitors. Bioorg. Med. Chem. 2006, 14, 4047-4054. [CrossRef]

31. Sandanayaka, V.P.; Prashad, A.S.; Yang, Y.; Williamson, R.T.; Lin, Y.I.; Mansour, T.S. Spirocyclopropyl beta-lactams as mechanismbased inhibitors of serine beta-lactamases. Synthesis by rhodium-catalyzed cyclopropanation of 6-diazopenicillanate sulfone. $J$. Med. Chem. 2003, 46, 2569-2571. [CrossRef] [PubMed]

32. Ellis, D.; Kuhen, K.L.; Anaclerio, B.; Wu, B.; Wolff, K.; Yin, H.; Bursulaya, B.; Caldwell, J.; Karanewsky, D.; He, Y. Design, synthesis, and biological evaluations of novel quinolones as HIV-1 non-nucleoside reverse transcriptase inhibitors. Bioorg. Med. Chem. Lett. 2006, 16, 4246-4251. [CrossRef]

33. Link, J.O.; Taylor, J.G.; Xu, L.; Mitchell, M.; Guo, H.; Liu, H.; Kato, D.; Kirschberg, T.; Sun, J.; Squires, N.; et al. Discovery of ledipasvir (GS-5885): A potent, once-daily oral NS5A inhibitor for the treatment of hepatitis C virus infection. J. Med. Chem. 2014, 57, 2033-2046. [CrossRef]

34. Elinson, M.N.; Vereshchagina, A.N.; Tretyakova, E.O.; Bushmarinov, I.S.; Nikishin, G.I. Stereoselective Electrocatalytic Cyclization of 4,4'-(Arylmethylene)bis(1H-pyrazol -5-ols) to (5R*,6R ${ }^{*}$-11-Aryl-4,10-dimethyl-2,8-diphenyl-2,3,8,9tetraazadispiro[4.0.4.1] undeca-3,9-diene-1,7-diones. Synthesis 2011, 3015-3019. [CrossRef]

35. Elinson, M.N.; Dorofeeva, E.O.; Vereshchagin, A.N.; Nasybullin, R.F.; Egorov, M.P. Electrocatalytic stereoselective transformation of aldehydes and two molecules of pyrazolin-5-one into $\left(R^{*}, R^{*}\right)$-bis(spiro-2,4-dihydro-3H-pyrazol-3-one)cyclopropanes. Catal. Sci. Technol. 2015, 5, 2384-2387. [CrossRef]

36. Itokawa, M.; Miyata, T.; Arai, M. Detection and Treatment of Schizophrenia. U.S. Patent 8,809,329 B2, 19 August 2014.

37. Rodríguez-Gutiérrez, S.V.; Barreiro-Costa, O.; León, C.D.A.; Heredia-Moya, J. Synthesis and Leishmanicidal Activity of Molecular Hybrids 1,2,3-Triazole-Chalcones. Chem. Proc. 2021, 3, 8356. [CrossRef]

38. Teran, R.; Guevara, R.; Mora, J.; Dobronski, L.; Barreiro-Costa, O.; Beske, T.; Pérez-Barrera, J.; Araya-Maturana, R.; Rojas-Silva, P.; Poveda, A.; et al. Characterization of Antimicrobial, Antioxidant, and Leishmanicidal Activities of Schiff Base Derivatives of 4-Aminoantipyrine. Molecules 2019, 24, 2696. [CrossRef] [PubMed]

39. Karimi-Jaberi, Z.; Shams, M.M.R.; Pooladian, B. Expeditious, four-component synthesis of 1,4-dihydropyrano[2,3-c]pyrazole derivatives catalyzed by trichloroacetic acid or ceric sulfate. Acta Chim. Slov. 2013, 60, 105-108.

40. Jin, T.; Zhao, R.; Li, T. An one-pot three-component process for the synthesis of. Int. J. Mol. Sci. 2006, 176-182.

41. Dorofeeva, E.; Elinson, M.; Vereshchagin, A.; Nigmatov, A.; Bushmarinov, I.; Nikishin, G. Stereoselective Thermal Isomerization of Bis(spiropyrazolone)cyclopropanes into (4Z)-4-[(Pyrazol-4-yl)methylene]pyrazolones. Synlett 2013, 24, 827-830. [CrossRef]

42. Xiaoliu, L.; Daming, D.; Yongmei, W.; Jiben, M. Solid state reactions of nitrogenous heterocyclic compounds (I)—Solid state reactions of 3-methyl-1-phenyl-5-pyrazolone with carbonyl compounds. Sci. China Ser. B Chem. 1997, 40, $205-214$.

43. Lipinski, C.A.; Lombardo, F.; Dominy, B.W.; Feeney, P.J. Experimental and computational approaches to estimate solubility and permeability in drug discovery and development settings. Adv. Drug Deliv. Rev. 2001, 46, 3-26. [CrossRef]

44. Sander, T.; Freyss, J.; Von Korff, M.; Rufener, C. DataWarrior: An open-source program for chemistry aware data visualization and analysis. J. Chem. Inf. Model. 2015, 55, 460-473. [CrossRef] [PubMed]

45. Alvar, J.; Vélez, I.D.; Bern, C.; Herrero, M.; Desjeux, P.; Cano, J.; Jannin, J.; Boer, M. den Leishmaniasis Worldwide and Global Estimates of Its Incidence. PLoS ONE 2012, 7, e35671. [CrossRef]

46. World Health Organization. Research Priorities for Chagas Disease, Human African Trypanosomiasis and Leishmaniasis; Technical Report of the TDR Disease Reference Group on Chagas Disease, Human African Trypanosomiasis and Leishmaniasis; WHO Technical Report Series; WHO: Geneva, Switzerland, 2012; Volume 975, pp. 26-29.

47. World Health Organization. Control of the Leishmaniasis: Report of a Meeting of the WHO Expert Committee on the Control of Leishmaniases; WHO Press: Geneve, Switzerland, 2010; Volume 949, pp. 54-73.

48. Uzcanga, G.; Lara, E.; Gutiérrez, F.; Beaty, D.; Beske, T.; Teran, R.; Navarro, J.-C.; Pasero, P.; Benitez, W.; Poveda, A. Nuclear DNA replication and repair in parasites of the genus Leishmania: Exploiting differences to develop innovative therapeutic approaches. Crit. Rev. Microbiol. 2016. [CrossRef]

49. Croft, S.L.; Olliaro, P. Leishmaniasis chemotherapy-challenges and opportunities. Clin. Microbiol. Infect. 2011, 17, 1478-1483. [CrossRef] 
50. Stirke, A.; Celiesiute-Germaniene, R.; Zimkus, A.; Zurauskiene, N.; Simonis, P.; Dervinis, A.; Ramanavicius, A.; Balevicius, S. The link between yeast cell wall porosity and plasma membrane permeability after PEF treatment. Sci. Rep. 2019, 9, 14731. [CrossRef] [PubMed]

51. Aouida, M.; Tounekti, O.; Belhadj, O.; Mir, L.M. Comparative Roles of the Cell Wall and Cell Membrane in Limiting Uptake of Xenobiotic Molecules by Saccharomyces cerevisiae. Antimicrob. Agents Chemother. 2003, 47. [CrossRef] [PubMed]

52. Singh, A.; Mahto, K.K.; Prasad, R. Lipidomics and in vitro azole resistance in Candida albicans. OMICS 2013, 17, 84-93. [CrossRef] [PubMed]

53. Ganeva, V.; Galutzov, B.; Teissie, J. Evidence that Pulsed Electric Field Treatment Enhances the Cell Wall Porosity of Yeast Cells. Appl. Biochem. Biotechnol. 2014, 172, 1540-1552. [CrossRef] [PubMed]

54. Pérez-Cantero, A.; Thomson, P.; Paredes, K.; Guarro, J.; Capilla, J. Antifungal susceptibility of Saccharomyces cerevisiae and therapy in a murine model of disseminated infection. Rev. Iberoam. Micol. 2019, 36, 37-40. [CrossRef]

55. Olive, P.L.; Banáth, J.P. The comet assay: A method to measure DNA damage in individual cells. Nat. Protoc. 2006, 1, 23-29. [CrossRef]

56. Dhawan, A.; Bajpayee, M.; Parmar, D. Comet assay: A reliable tool for the assessment of DNA damage in different models. Cell Biol. Toxicol. 2009, 25, 5-32. [CrossRef]

57. Mahajan, P.S.; Nikam, M.D.; Khedkar, V.; Jha, P.; Badadhe, P.V.; Gilla, C.H. An Organocatalyzed Efficient One-pot Synthesis, Biological Evaluation, and Molecular Docking Studies of 4,4'-(Arylmethylene)bis-(3-methyl-1- phenyl-1H-pyrazol-5-ols). J. Heterocycl. Chem. 2017, 54, 1109-1120. [CrossRef]

58. Zolfigol, M.A.; Ayazi-Nasrabadi, R.; Baghery, S. Synthesis and characterization of two novel biological-based nano organo solid acids with urea moiety and their catalytic applications in the synthesis of 4,4'-(arylmethylene)bis(1H-pyrazol-5-ol), coumarin-3carboxylic acid and cinnamic ac. RSC Adv. 2015, 5, 71942-71954. [CrossRef]

59. Shirini, F.; Seddighi, M.; Mazloumi, M.; Makhsous, M.; Abedini, M. One-pot synthesis of 4,4 -(arylmethylene)-bis-(3-methyl-1phenyl-1H-pyrazol-5-ols) catalyzed by Brönsted acidic ionic liquid supported on nanoporous Na+-montmorillonite. J. Mol. Liq. 2015, 208, 291-297. [CrossRef]

60. Frankowski, K.J.; Liu, R.; Milligan, G.L.; Moeller, K.D.; Aubé, J. Practical Electrochemical Anodic Oxidation of Polycyclic Lactams for Late Stage Functionalization. Angew. Chem. Int. Ed. 2015, 54, 10555-10558. [CrossRef] [PubMed]

61. Yang, C.; Pang, L.; Wang111, A. Synthesis of 4,4'-Arylmethylene-bis(3-methyl-5-pyrazolones) using Diammonium Hydrogen Phosphate as an Efficient and Versatile Catalyst in Aqueous Media. Asian J. Chem. 2011, 23, 749-751.

62. Romero-Benavides, J.C.; Ortega-Torres, G.C.; Villacis, J.; Vivanco-Jaramillo, S.L.; Galarza-Urgilés, K.I.; Bailon-Moscoso, N. Phytochemical Study and Evaluation of the Cytotoxic Properties of Methanolic Extract from Baccharis obtusifolia. Int. J. Med. Chem. 2018, 2018, 1-5. [CrossRef]

63. Oliveira, R.; Johansson, B. Quantitative DNA Damage and Repair Measurement with the Yeast Comet Assay. In DNA Repair Protocols; Bjergbæk, L., Ed.; Methods in Molecular Biology; Humana Press: Totowa, NJ, USA, 2012; Volume 920, pp. 101-109. [CrossRef]

64. Les, F.; Prieto, J.M.; Arbonés-Mainar, J.; Valero, M.; López, V. Bioactive properties of commercialised pomegranate (Punica granatum) juice: Antioxidant, antiproliferative and enzyme inhibiting activities. Food Funct. 2015, 2049-2057. [CrossRef] [PubMed]

65. Nikzad, S.; Baradaran-Ghahfarokhi, M.; Nasri, P. Dose-response modeling using MTT assay: A short review. Life Sci. J. 2014, 11, 432-437. [CrossRef]

66. Foulet, F.; Botterel, F.; Buffet, P.; Morizot, G.; Rivollet, D.; Deniau, M.; Pratlong, F.; Costa, J.M.; Bretagne, S. Detection and identification of Leishmania species from clinical specimens by using a real-time PCR assay and sequencing of the cytochrome $b$ gene. J. Clin. Microbiol. 2007, 45, 2110-2115. [CrossRef] [PubMed] 